Fekete Csaba

\title{
Debrecen imádságos énekeskönyvének (1641) imádságai (RMNy 1874)
}

Hazai protestáns imádságaink története, valamint a kéziratosság szempontjából tekintem át ennek az egyedi kiadványnak egyes vonásait. Remélem, a további kutatás kiegészíti vagy eldönti a kutatás eddig válasz nélkül maradt kérdéseit és legalább részben pótolja hiányos ismereteinket.

Keresztyéni imádságok egy-néhány szép énekekkel a kötet címe a hiányos címlap szerint. Nem az RMNy betü szerinti leírását idézem, átírom. A tanulmány végén közölt ábrák kiegészítik az RMNy leírását. Ezek sorban: a kolozsvári félcímlap és a mögüle kilátszó első lap egyik része, valamint a tulajdonbélyegző (1/1. és $1 / 2$. ábra), ${ }^{1}$ Lugossy kéziratos címlap-kiegészítése a kolozsvári csonka példányban (2. ábra), a Lugossy-féle debreceni foszlány egyik levelének képe a kenyérbetüvel (3. ábra), ${ }^{2}$ az OSZK példányából az előszó végét, a nagyobb fokozatú betüt, a kurzívot és a kötetben található záródíszt mutatja (4. ábra). ${ }^{3}$ Elkeveredett korábban, de elökerült a kiáztatott pataki címlap töredéke is. Ez azonban nem az 1641-es címlap, hanem Fodorik másik nyomtatványához tartozik (5. ábra). ${ }^{4}$ Mindvégig HALA-ADASOK ES DICSIRETEK az élőfej, a korai meghatározó kísérletek közül egyik ezt címnek tekintette, az OSZK példányán ezért olvasható kézírással: „Hálaadások és Dicséretek”. H. Hubert

1 Központi Egyetemi Könyvtár, Kolozsvár, Különgyüjtemények (Biblioteca Centrală Universitară „Lucian Blaga”, Cluj-Napoca, Colecţii Speciale), BMV 2193.

2 TTREK (Tiszántúli Református Egyházkerületi Nagykönyvtár) Rmk 1349. Vö. OláH Róbert, A Tiszántúli Református Egyházkerületi Nagykönyvtár RMK-katalógusa, Tiszántúli Református Egyházkerületi Gyüjtemények, Debrecen, 2021 (A Tiszántúli Református Egyházkerületi Gyüjtemények kiadványai), 220.

3 RMK I. 713. - A Lipsiai Rheda és a Fodorik nyomda betüire és díszeire vö. BÁNFI Szilvia, Pavercsik Ilona, Perger Péter, V. Ecsedy Judit, A régi magyarországi nyomdák betüi és díszei, XVII. század, 2. kötet, Kelet-magyarországi és erdélyi nyomdák, Lőcse, Kassa, Tanulmányok és Katalógus, Bp., Balassi, OSZK, 2014 (Hungaria Typographica, II), 67-69, IV/4.

${ }^{4}$ A Sárospataki Református Kollégium Tudományos Gyüjteményei, töredékek, N 1347 és N 1364. A kiáztató Harsányi István nem vette észre, hogy nem minden levél az 1641-es nyomtatványból származik, későbbi imádságos könyvből való egyik részük. Vö. PAVERCsıK Ilona, A sárospataki könyvtár értékes töredékeiről = Translatio librorum, Tanulmányok az Oroszországból Sárospatakra visszaszolgáltatott könyvek kapcsán, szerk. Jekatyerina Jurjevna Genyijeva, Kiss Ilona, Monok István, Bp., OSZK, 2007, 133-134. 
Gabriella összegezte a gyér irodalmat. ${ }^{5}$ Csonka példányok meghatározási kísérleteként keletkezett, részben téves; például Szabó Károly a kolozsvári csonka példány formátumát $12^{\circ}$-nek vélte, az OSZK példányán is ez található kézírással. Maga a könyvmüfaj a szakirodalomban csupán egy tucat kiadványra korlátozódik. ${ }^{6}$ Ide soroljuk legkorábbiként a mai példány szerint ismeretlen 16 . századi unitárius kiadást, erre Enyedi György utal. ${ }^{7}$ Ezekben a kiadványokban rendezőelv az imádságok elsődleges jelenléte, úgy, hogy hozzájuk társulnak az énekek, és nem fordítva. Távolabbi ellenpéldái és rokonai a müfajnak azok a gyülekezeti énekeskönyvek, amelyekben hol csak néhány, hol egész sorozat imádság is van, függelékül, de nem az énekek közé sorolva, és mindig az énekek közlése döntő. Másrészt különféle, főként kegyességi munkákhoz nemritkán csatoltak énekeket, némelykor valamennyi imádságot is.

Az imádság-ének szerkezethez képest van 1641-ben néhány eltérés. A négy hitvallást öt imádság tömbje követi, az Atyához, a Fiúhoz, és három a Szentlélekhez. Erre következnek, itt bevezető imádság nélkül, az egyházi év saját énekei, kezdve az adventiekkel. Folyamatos azonban a levélszámozás, azaz nem kezdték újra a nyomtatást, pedig a $18^{\circ}$ formátumú kötetben a füzetek számozása megfordult, előbb $10+8$ volt A-Z jelöléssel, Aa-Xx viszont $8+10$. Végül a betegekért, meghalókért, utolsó ítéletért való hat imádság lezáró tömbje után egyetlen ének van, erre következik, újabb bevezető imádság nélkül, az összes halotti ének. A levélszámozás itt is folyamatos, ezért a szerkezeti eltérés magyarázata a felhasznált több eltérö, egykor létezett forrás lehet. Ezeket nem ismerjük, az alább felderített néhány kapcsolat mutatja, hogy nyomtatványok is lehetnek, valamint ezek kéziratos előzményei vagy származékai.

Többlet a példányok korábbi nyilvántartásához képest, hogy van Debrecenben is kötéstáblából származó, csupán tucatnyi levélre terjedő töredék, a kiáztatás Lugossy József érdeme, ${ }^{8}$ aki ezt Harsányival nagyjából egy időben végezte, és saját csonka példányát az Erdélyi Múzeumnak ajándékozta. ${ }^{9}$ Sárospatak nyolcvanhárom levélnyi csonka példányát szintén kötéstáblából áztatta ki Harsányi István a 19. század végén, közöttük, ö úgy vélte, a címlap alsó része is megvan. ${ }^{10}$

${ }^{5}$ H. HuBert Gabriella, A régi magyar gyülekezeti ének, Bp., Universitas, 2004 (Historia Litteraria, 17, Evangélikus Gyüjteményi Kiadványok, 2) 256-259, 458-460. - Nehézkessége miatt nem használom a H. Hubert Gabriella választotta 'ima-énekeskönyv' müfaji megnevezést, azért sem, mert a kötetben 'imádság' olvasható, nem a nyelvtörténetileg kései 'ima' szóalak.

${ }^{6}$ Az itt tárgyalton kívül ide tartozik még az RMNy 746, 1290, 1459, 1552, 2146, 2319, RMK I. 1308-1309, 1334, 1558-1559.

7 RMNy 746: H. Hubert 2004, i. m. 254-255, 388.

8 A könyv címe, amelynek kötéstáblájából származik, nem maradt meg; a töredék mai jelzete TTREK, Rmk 1349. Vö. OLÁH 2021, i. m. 220, a 3. lábjegyzetben.

${ }^{9}$ Lásd az ábrákat, ezeket a Központi Egyetemi Könyvtár, Kolozsvár szívességéböl közölhetem, a kollegiális segítséget Luffy Katalinnak köszönöm.

${ }^{10}$ Nyizsnyij Novgorodból (más töredékekkel) a Harsányi kiáztatta töredék hazakerült Patakra; a nyilvános olvasói katalógusban nem szerepel. Lásd PAVERCSIK 2007, i. m. ismertetését a 4. lábjegyzetben. Formátuma miatt sem lehet az 1641-es nyomtatvány címlapja, mert az $5 \times 3,1 \mathrm{~cm}$ méret 
Immár négy csonka példányról tudunk. Legteljesebb az OSZK címlaptalan példánya, ebből mindössze négy levél hiányzik. Néhány lapszám hibás: N8a - 160 recte 109; R5a - 124 recte 142; Mm6a - 350 recte 305.

Az imádságok jövőbeli kutatása és áttekintése érdekében szükségesnek látszott az RMNy tartalmi leírását kiegészítenünk, azaz elkészítenünk az imádságok saját mutatóját. Ennek megokolása alább következik. Előtte azt lássuk, hogy bár terjedelme ezt nem követelné, mégis müfajilag ide sorolhatunk még egy rokon tételt, főleg a megnyitó imádság kapcsolódása miatt.

\section{Egy hasonló müfaj korábbi példája (1597)}

Gratiarum actio a címe ennek az imádságos énekeskönyvnek. Nyolcleveles kis füzet. ${ }^{11}$ Tartalma három imádság, egy himnusz, két zsoltárparafrázis és egy históriás ének. Előszava nincs, szerkesztője ismeretlen. Talán alkalmilag jelent meg. Szerencsére egy példányát valamelyik peregrinus diák magával vitte külföldre, Halléban érintetlenül megmaradt. H. Hubert Gabriella nem sorolja az itt tárgyalt müfajhoz. Részben terjedelme, valamint Gulyás Pál vélekedése miatt, aki iskolai kiadványnak tekintette. Helytelenül. Igaz, van benne egy levélen Kicsin gyermekeknek, reggeli és estvéli imádság. Ráfoghatjuk azt is a kiadványra, hogy az iskolásoknak ismerniük kellett az esti himnuszt (Krisztus, ki vagy nap és világ) ${ }^{12}$ az 51. bünbánati zsoltárt (Úr Isten, irgalmazz nékem), ${ }^{13}$ és Luther 46. zsoltárát (Erös várunk). ${ }^{14}$ Ahhoz már igencsak nyakatekert logika kellene, hogy kisiskolás tananyagnak minősítsük Egri C. Miklós Nagy keservesen felséges Isten seregeknek ura kezdetü históriás énekét. ${ }^{15} \mathrm{~A}$ három évvel korábban átélt tatár betörés borzalmait panaszolja, egyetlenegyszer itt jelent meg, tizenhatos sorokból áll $(5+5+$

nem $18^{\circ}$, hanem nagyobb, $8^{\circ}$ kiadványhoz illik. Véleményem megerősítését Bánfi Szilviának és Pavercsik Ilonának köszönöm. Személyesen nem kutathattam most, Tanászi Árpádtól és Éger Gábortól kaptam tájékoztatást, a címlaptöredék képével együtt.

${ }_{11}$ Gratiarum actio cum adjunctu precatione pro universis acceptis spiritualibus et corporalibus Dei optimi beneficii etc, RMNy 798.

12 RPHA 804.

13 RPHA 1436.

14 RPHA 392.

15 A címben olvasható évszám nem jelenti, hogy még ugyanabban az évben megírta vagy meg is jelent volna, valójában 'ante 1597' a pontosabb keltezés. RPHA 1036. Vö. RMKT XVII, 128 130, 501-502. A két Wittenbergben tanult Egri Miklós közül nem a két évtizeddel idősebb, hanem a diáktestületbe 1585. május 28-án belépett Nicolaus C. Agrius Ungarus a szerző. 1590-1609 között ő volt Nagyszőlős prédikátora, és mert összeütközött esperesével, Beregtől elszakítva Ugocsához sorolták a helységet 1609-ben. A tatárok Ugocsán át törtek be. Ez az Egri Miklós volt többször zsinaton Bátorban, az nem bizonyos, hogy ő volt Sajóvelezd prédikátora $(1620,1623)$. Nincs adatunk, hogy milyen kapcsolata volt Debrecennel. Összegzi ismereteinket a szerzőről SzABó András, Coetus Ungaricus, A wittenbergi magyar diáktársaság 1555-1613, Bp., Balassi, 2017 (Humanizmus és Reformáció, 37), 135. 
6), Nagybáncsai énekének dallamára énekelhető. A hasonmását 1909-ben kiadó Obál Béla az egész füzetet Nicolaus Agrius nevével jegyezte, mintegy őt vélte szerkesztőnek is, vagy kiadónak. Bizonygatni ezt sem volna nehezebb, mint azt, hogy ez a kiadvány kisiskolás tananyagként készült.

Továbbá az 1597-es füzet címe nem jelenthet, különösen kezdete nem is sejtet semmiféle iskolai múfajt; a kezdő imádságnak a gyermekeknek való imádságpárhoz viszonyított terjedelme miatt is aligha született kicsiknek. Alkalmas mindennapi könyörgésnek, templomban, otthon, akár úrvacsorai szertartásban. Elterjedt megnevezés volt az elbocsátás és áldás elött elhangzó hálaadásra, például Alvinci Kassai Ágendájában (1622), nála emez imádság felirata Gratiarum actio. 1641ben rövidítve jelent meg ez az imádság. A kéziratossággal való kapcsolatot is tetten érjük ugyanitt. Budakeszi György 1621-ben összeírt Ágendája után imádságok is következnek, ${ }^{16}$ az első közöttük: Oratio quotidiana. Ez nem más, mint hosszabb változata az 1641-ben, az (I)-es szakaszban olvasható egyik reggeli imádságnak, a Gratiarum actio füzetében pedig ez a kezdő imádság. Csúzban, Komárom megye udvardi járásában (Érsekújvártól keletre) müködött vagy élt akkor a leíró ifjú prédikátor. Felvidéken tehát szintén ismert és használt lehetett a Szenci Molnár Albert közreadta imádság. Ez az Oppenheimi Bibliához (1612) ${ }^{17}$ mellékelve jelent meg, csaknem teljesen egyező párja annak, amit a Gratiarum actio első lapjain találunk. Szenci Molnárnál felirata: Hálá adás az elvött jókért, és könyörgés az elvejendökért. Ez a felirat is megjelenik 1641-ben. Hagyományos imádság a párja is, amellyel együtt közölte Szenci Molnár, az Oppenheimi Biblia élőfeje szerint, megmondva, hogy e kettő a debreceni eklézsia imádsága. Rövidebb bekezdésekre tagolódik a nyomtatott változat, mint Budakeszi kézirata. Zsoltárköltőnk forrására nem utal, debreceni diák korában tanulhatta. A szöveg összehasonlítása azt mutatja, hogy a csúzi kéziratos változat nem lehet egyik nyomtatott forrás gépies másolata. Szó szerint egyező szakaszok közben ismételten fölbukkannak apróbb-nagyobb különbözések, hol a Gratiarum actio, hol az Oppenheimi Biblia szövegétől eltérő szószerkezetek vagy mondatok, ezek használattal is, de szóbeli és kéziratos terjedéssel magyarázhatók sokkal inkább, mint tudatos szerkesztői változtatással. Hasonlítsuk össze a két változatot:

16 Bukarest, Akadémiai Könyvtár, Mss Maghiar, No. 32. Vö. Fekete Csaba, Csallóközi formula avagy református ágenda a 16-17. századból = Monokgraphia, Tanulmányok Monok István 60. születésnapjára, szerk. Nyerges Judit, Verók Attila, Zvara Edina, Bp., Kossuth, 2016, 202-208. Tervezem későbbi kiadását, több kéziratos Ágenda, töredék és kéziratos imádság jegyzetelt példáival együtt. Ezért itt nem foglalkozom a kérdés részleteivel.

17 RMNy 1037. 


\section{Csúz}

Örök mindenhato kegyelmes Atya, élö Úr Isten, ki vagy mennynek és földnek teremptö Istene, az mi Urunk Jézus Kristusnak szerelmes szent Atyja!

Hálákat adunk mi te szent fölségednek, mint kegyelmes Atyánknak és Istenünknek, az te mi hozzánk való jó voltodért és kegyelmességedért, hogy te minket ez világra az te személyedre teremtöttel, föl tartottál, neveltél, és az te tál

egyetlen egy Fiadnak, az mi Urunk Jézus Kristusnak szent halálával meg szabaditottál az ördögnek hatalmából.

Annak fölötte ez éjjel is meg ótalmaztál minden lölki és testi vészedelemtül, egészséggel és békességgel jutattál ez mái napra is, kiért hálá légyenn te szent fölségednek mind örökké! Te szent fölségednek kezeibenn ajánljuk mind lelkünket, és mind testünket, minden egyéb féle ajándékoddal egyetembenn. Könyörgünk azért te szent fölségednek, miként kegyelmes Atyánknak, bocsásd meg az mi sok számtalann büneinket, és örizz meg minket minden te ellened valo bünben esséstül.

Adjad minékünk, óh, Úr Istenn, az te Szent Lelkedet, hogy ez mái naponn is, és életünknek minden idejében, élhessünk az te szentséges nevednek tiszteletire, lölkünknek idvességére, és felebarátinknak epületekre.

Örizz meg minket, óh, Úr Istenn, mindenn lelki és tésti vészedelemtül, az ördögnek csalárdságátúl, ellenséginknek gonosz szándékjoktúl, és kegyetlenn birodalmoktul, dög halaltúl, hertelen halaltúl, mindenn nyomorúságtúl és kárvallástúl.

\section{Debrecen}

Örök, mindenható, kegyelmes Úr Isten, mennynek és földnek teremtöje, mi Urunk Jézus Kristusnak szerelmes szent Atyja!

Hálákat adunk mi te néked, hogy minket ez világra az te képedre teremtettél, föl tartottál, neveltél, és az te szent Fiadnak halálával az pokolbéli ördögnek hatalmasságából meg váltot-

Annak fölötte, hogy minket ez éjjelen meg őriztél minden testi és lelki veszedelmektül, egészséggel és békeséggel virrasztottál ez mái napra, légyen hála te szent fölségednek, Ez napon is az mi testünket és lelkünket te szent fölségednek kezeiben ajánljuk, minden te ajándékiddal egyetemben, És viszontag könyörgünk te szent fölségednek, bocsásd meg az mi számlálhatatlan sok büneinket, őrizz meg, ótalmazz meg ellened való bünben eséstül.

Adjad az te Szent Lelkedet, hogy ez mái napon és minden időben élhessünk te szent nevednek tisztességére, lelkünknek idvösségére, felebarátunknak épületire.

Örizz meg testi és lelki veszedelemtül, az pokolbéli ördögnek incselkedő gonosz csalárdságátúl, gonosz embereknek gonosz szándékoktúl, dög haláltúl, hírtelen haláltúl, minden nyomorúságtúl, kétségben való eséstül, és kárhozattúl. 
Nem csupán némileg bővebb a kéziratos változat, hanem van még folytatása, amely mindenestül elmaradt 1641-ben, mert alighanem más forrásból került Debrecenbe. Erre alább visszatérünk.

Van aztán egy másik imádság, amely csekély különbséggel két év múlva ismét megjelent egyik több szempontból érdekes Ágendában, és majdnem fél évszázaddal később ismét föltünt, méghozzá egy Biblia függelékeként. Ez az RMNy szerinti (XXV), helyesbítve (XXIV) számú szakasz kezdö imádsága. Láthatjuk ebböl, hogy lehet több évtizedes háttere és lehetett a gyakorlatban folytatódó használata szinte bármelyik imádságnak, amely alkalminak vagy egyszerinek látszik.

\section{Paksi K. György Ágendája $(1643)^{18}$}

Pataki diák volt a dunamelléki püspök (kb. 1615-1651/1652), majd kecskeméti és rimaszombati prédikátor. Ismeretlenek forrásai, könyvtára, a hagyományhoz való kapcsolódása. Nincs miért feltételeznünk, hogy azonnal átvett imádságokat az 1641-es debreceni nyomtatványból. Nála föltünik két reggeli imádság, helyesírásuk eltér a debrecenitől. A harmadik imádságnak a helyesírása hasonlít az 1641-es kiadáséhoz, de a központozás gondosabb, nem hiányoznak az ékezetek, mindez semmit nem dönt el a származásáról. A bekezdések ugyanolyan rendben következnek egymás után, egyes szóalakok változása mellett néhány mondatban vannak eltérések, nincsen azonban semmiféle utalás az 1641-es kiadás beilleszthető reggeli imádságára, nem úgy, mint 1685-ben. Paksi Ágendájának az OSZKban őrzött példánya néhány helyen kéziratos kiegészítést tartalmaz 1700 tájáról, ezek egyike sem helyesbítés, de értelmileg beleillik a mondatba és a gondolatmenetbe, azaz ennek az imádságnak ismeretes lehetett és terjedhetett is helyenként eltérő vagy módosult változata.

18 RMNy 2043, 26-31. - Az imádság változata fölbukkan Drégelypalánki Jánosnál; róla tudjuk, hogy átszerkesztette vagy toldalékolta a Praxis pietatis imádságainak átvett részleteit. Vö. Fexete Csaba, A Pataki Ágenda és a Praxis pietatis = Könyv és Könyvtár, 25(2003), 65-98. Losonczi András török elől menekült debreceni diák Sárospatakon őrzött kéziratos gyüjteményének (1660-1662/1663) imádságai között, amelyek között valószínűleg nem saját szerzése egy sem, szintén megvan. Lásd a további részleteket FeKeTe Csaba, E' mi nyomorult városunkban... A Losonczi András-féle gyüjtemény (1660-1663) egyik imádságának szertartási háttere = Református Szemle, 102(2009), 432-438; Uö, ,, ...még a fészekböl kiesö verébfiókára is... ”, Adalék a Losonczy András-féle imádságok (1660-1662) hátteréhez és forrásaihoz = Egyháztörténeti Szemle, 10(2010/4), 87-89. Legutóbb áttekintette Paksi életét és munkáját PAP Ferenc, Paksi György ágendája = A Komáromi Selye János Egyetem 2015-ös „Innováció és kreativitás az oktatásban és a tudományban" nemzetközi konferenciájának tanulmánykötete, szerk. Juhász György et al., Komárom, Selye János Egyetem, 2015. A lehetséges forrásokra, a részletes feltártság hiányára és egyéb részletekre itt nem térek ki. 


\section{Tótfalusi Kis Miklós közlése (1685) ${ }^{19}$}

Háláadás az elvött jókért és könyörgés az elvejendökért ennek a terjedelmesebb imádságnak a felirata az Aranyas Bibliában, ahelyett, amit 1641-ben így olvasunk: Az Istennek minden lelki testi el vött és el-vejendö jovájért való hálá adás és könyörgés. Paksi K. Györgynél a cím: Hálá-adás és könyörgés az Istennek minden lelki és testi el-vött és el-vejendő jó téteményiért. Különbség még, hogy 1685-ben alkalmilag választható rövid toldalék is van, vele egy szintén beiktatható reggeli vagy esteli szakasz. 1641-ben ennek helyén szintén van egy beiktatható szakaszra utalás a reggel vagy este egyaránt mondható imádságból. Paksinál ellenben nincs nyoma.

Párhuzamosan elég itt látnunk egy jellemző szakaszt. Többnyire szó szerinti az egyezés, csupán egy-egy bővítmény marad el a Biblia végén közölt imádságból.

1641 Debrecen

Oltalmazz meg, Uram Isten, szomszédságinkban lévő keresztyén országokkal, tartományokkal, várasokkal, falukkal, és azokban lévő híveiddel és szolgáiddal egyetemben, minket is, várasunkkal, eklézsiánkkal, és házunk népével egyetemben, minden lelki és testi veszedelmektül, kiváltképpen az ördögtül, annak álnokságátúl, csalárdságátúl, hamis tudományátúl veszedelmes kísírtetitül, ártalmas tagaitúl, veszedelmes hadaktúl, rablástúl, dúlástúl, tüztül, éhségtül, drágaságtúl, veszedelmes betegségektül, hírtelenben való haláltúl, égi háborúktúl, szélvészektül, ragyáktúl, kő-essőktül, menny-ütő kövektül, veszedelmes árvizektül, bünben való eséstül, gonosz hírtül, névtül, gyalázattúl, gonosz lelkiismérettűl, kétségben való eséstül és kárhozattúl.

\section{Amszterdam}

Oltalmazz-meg Uram Isten, szomszédságinkban lévő keresztyén országokkal, tartományokkal, várasokkal, falukkal, és azokban lévő híveiddel és szolgáiddal egyetemben, minket is, várasunkkal, eklézsiánkkal és házunk népével egyetemben minden lelki és testi veszedelmektől, kiváltképen az ördögtől, annak álnokságától, csalárdságától, hamis tudományától, veszedelmes kísértetitôl, ártalmas tagaitól, veszedelmes hadaktól, háborúságtól, rablástól, dúlástól, tüztől, éhségtől, drágaságtól, veszedelmes betegségektől, hírtelen való haláltól, égi háborúktól, vészektől, ragyáktól, kő-esőktől, menny-ütő kövektől, veszedelmes árvizektől, bünbe való eséstől, gonosz hírtől névtől gyalázattól, gonosz lelki esmérettől, kétségbe való eséstől és kárhozattól.

19 RMK I 1324. 
Ótalmazz meg, Uram Isten, mind most, mind ennek utánna való időkben, idegen népeknek messze földröl hírtelen rejánk jövetelektül; közel valóknak penig ki ütésektül, kártételektül, és fegyverektül.
Oltalmazz-meg Uram Isten, mind most, s mind ennekutánna való időkben, idegen népeknek reánk ütésektől, kár-tételektől, és fegyverektől.

Legnagyobb a különbség a szabadon választható és tetszés szerint beilleszthető függelékben van, ennek csak a nyitánya azonos. Ez az a részlet, amely Paksi K. Györgynél teljesen hiányzik.

1641 Debrecen

Más könyörgés, melyet mind reggel $s$ mind estve mondhatni

Úr Isten, mi kegyelmes szerelmes és szent Atyánk! Ki minden állatoknak, nagyoknak és kicsinyeknek, kegyelmes gondja viselője, oltalmazója, és tápláló Atyja vagy! Nagy hálákat adunk te szent fölségednek, minden időbeli gond-viselésedért, (ez éjtszakai) (ez mái táplálásodért), oltalmazásodért is, szent Fiadnak, az Jézus Kristusnak általa. Ámen. ${ }^{20}$
1685 Kolozsvár

\section{Reggel}

Úr Isten, mi kegyelmes szerelmes és szent Atyánk, e jelen való napot is tedd nékünk békességessé és egészségessé, hogy a mi keresztyéni tisztünben szorgalmatosban eljárhassunk.

\section{Estve}

Úr Isten, mi kegyelmes szerelmes és szent Atyánk, e következendő éjszakát is tedd minékünk békességessé és nyugodalmassá, hogy a hólnapi napra felvirradván a mi keresztyéni tisztünkben szorgalmatosban eljárhassunk.

Hány imádság jelent meg 1641-ben?

Nem hetvenegy imádság jelent meg 1641-ben. Azért látszik ennyinek, mert csak az énekek incipitjét és lapszámát mutatózta az RMNy 2000-ben. Imádságok énekekkel azonos mutatózása alig is lehetséges, mert nincs hasonló kezdősoruk. Láthattuk a feliratok vagy címek föntebbi néhány példájában, hogy azonos tartalmú vagy teljesen megegyező szövegü imádságoknak lehet eltérő vagy csak nagyjá-

${ }^{20}$ Csak a szabadon beilleszthető bekezdés kezdetét jelzi a kézirat: „Úr Isten, mi kegyelmes szer[ető mennyei Atyánk] Vide supra fol. 5." — Ez a mind reggel, mind este mondható imádság része, végén ámennel, amint láttuk. Következik még utána egy szakasz, amely teljesen elmarad 1641-ben. 
ból egyező címe, felirata. Sok imádság (nem ritkán többszörösen) bővített megszólítást ismétel kezdetként, a folytatása viszont eltér. Ez az indexelés terjedelme miatt gond. Nem elég azonosításhoz az első nyomtatott sor, vagy csak pár szó, gyakran elkerülhetetlen hosszabb incipit részlete mellett még néhány jellegzetes szószerkezet, azaz több félmondat közlése.

Az RMNy tehát a kötet tartalmát (I)-(LXXI) szakaszra bontotta. Csak a szakaszt kezdő imádság feliratát közli, a többiét nem. Azt sem jelzi, ha egymás után még másik vagy több imádság következik. Az énekektől való elkülönítés érdekében hiányzik az imádságok kötetbeli lapszáma. Mindjárt az (I) számhoz öt imádság tartozik; ennek „Reggeli és esti imádságok” összefoglaló felirata nem is a kötetből való, ott az első négy imádság után következnek a reggeli énekek; majd külön szakaszt alkot az egyetlen esti imádság, ez után következnek az esti énekek. 1641-ben tehát nincs összevonás. Más szakaszok sem mind egyetlen imádságot jelentenek. Például az asztali áldás kettőt, az étel utáni hálaadás hármat, a foglyoknak való és a keresztelési szakasz négyet-négyet, a hálaadó úrvacsorai szakasz ötöt stb.

Tévedés a (XVII) szakasz imádságként való mutatózása: Az mi urunk Jézus Kristus kín-szenvedésének és halálának rövid históriája nem magában álló imádság felirata, hanem a megelőző (XVI) szakaszhoz tartozó rímes-strófikus passió-éneké. Kezdősora: Az mi urunk Jézus Kristus $\mid$ mint szenvede mi érettünk. ${ }^{21} \mathrm{Ez}$ a szakasz törlendő az imádságok közül. A javított számozás így (I)-(LXX). Ez volna, ámde ezen még más pontosítani való is akad.

Összegző címmel egybefoglalhatta volna az RMNy a kereszteléshez kapcsolódó imádságokat, mint az (I) szakaszban, de itt nem tette. Ellenben a házasok imádságát három szakaszként értelmezte, holott nyilvánvaló, hogy a házas ember, a házas asszony, majd mindkettőjük által mondott imádság egyetlen egység, ezt külön a férfi vagy a nő mondhatja, és együtt is mondhatják, közöttük nincs ének, csak a harmadik imádság után. Sőt csak a harmadik imádság végén van 'ámen', nincs az első két részlet után. Itt tehát az RMNy egy imádságot számozott háromnak. Külön-külön egységként számozta az utolsó szakaszt alkotó hat imádságot is az RMNy, lapszám nélkül; az 1641-es nyomtatott mutató mindig közöl lapszámot, ennél a hat imádságnál is. Közöttük nincs ének. Összetartozó négy imádság következik a keresztelési szakaszban, hálaadással és megemlékezéssel; közéjük egyetlen ének sem ékelődik. Végül a halottas énekek osztatlan tömbje követi a valójában egybetartozó (LXVII)-(LXXI) számozású szakaszt, ezt a betegség, halál mellett a feltámadás reménysége és az utolsó ítélet összefogott témája jellemzi.

Kedvezőtlen az imádságok kutatására bibliográfiai kézikönyvünk azon gyakorlata, hogy a kötet eredeti szakaszolását tükrözi vissza, és nem sorolja fel egyenként az egyes szakaszokban közölt imádságokat. 1641-ben az eredeti tagolás szerinti 71 imádságcsoportban jóval több imádság olvasható 71-nél.

211600 előtti ének, megjelent Debrecen, 1602-től ismételten (RMNy 983, RMNy 117. stb.), RPHA 0026, dallamának kiadása RMDT I 748. 
Az alább következő felsorolás, incipittel és lapszámozással, felöleli és mutatóba foglalja az ötvenkét szakaszt és százkilenc (vagy ha a házasok imádságát háromnak számoljuk, akkor száztizenegy) imádságot.

\section{Árulkodó 'i’'zés}

Ugyanaz a személy a kötet gyüjtője, összeállítója és az előszó írója. Erre utal egyes nyelvjárási szóalakok következetes használata 1641-ben. Tehát nem valaki más írt az elkészült kötethez ajánlást utólag, például a nyomdász. ${ }^{22}$ Ez lehetetlen, mert az első füzet levélszámozása folyamatos, ezt föntebb láttuk, a kötet előszavát nem nyomtathatták a könyvtest nyomtatásának befejezése után.

Az előszó mondanivalója illeszkedik az egész munkához, aztán például ugyanúgy a latin nyelvü Biblia alapján idéz, fejből és szabadon magyarítva, és csak részben követi Szenci Molnár Albert kiadását, akár csak az imádságok bibliai hivatkozásaiban és jelöletlen idézeteiben. A kötet keletkezéséről, céljáról, forrásairól semmit nem árul el az ajánlás.

Az egységes indexelés érdekében az RMNy nem őrizte meg, de az élőfejben végig 'dicsiretek' olvasható. Csaknem kivétel nélküli néhány szó következetes írása (í betűje nincs a nyomdának, a korabeli helyesírás nem is jelöli a hosszú

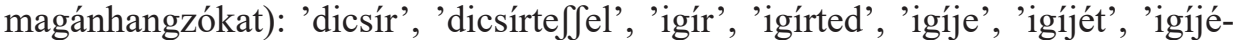
ben', 'itílet', 'itíleti' stb. Azért akad néha kivétel, mert az énekek nyelvjárása nem azonos, más szóalakokat szintén tartalmaznak. De ez a jellegzetes 'í'-zés végig megvan. Akkor is, ha például egy-egy ének vagy strófa végig 'ö'-ző. Ezeket vagy egyáltalán nem írta át a szerkesztő, vagy ha mégis, nem következetesen. Emellett más, egykor elterjedt szóalakok is vannak, például: 'szörzöttem volt', 'csendesz', 'békeség', 'el jü itílni', 'kéncset' stb. Ezek nehezen köthetők egyetlen vidékhez vagy egyetlen szerzöhöz. Egyes hangzók jelölésében is van helyenként különbség, mert a szokásos 'cz' (vagy 'tz') helyett 'cs' is fölbukkan a leghosszabb imádságban, a Dánielhez kapcsolódóban, azaz: 'gerlicse', 'kacsag', 'orcsa', 'utcsa' ('úcsáinkban'!). Alább visszatérünk erre az imádságra, földerített forrása miatt.

Debrecenben debreceni 'î'-zés várható, és az ország keleti részének 'í'-zése eltér a máshol tapasztalhatótól, például a Sylvester Jánosétól. Hallhatók voltak sủrủn még a múlt század hetvenes-nyolcvanas éveiben is piacon, kertségekben, boltban, utcán a debreceni nyelvjárás 'adjík', 'bújjík', 'faljík', 'jüjjík', 'tőtsík', 'várjík' stb. szóalakjai. Azóta ez ritkult, részben a beköltözők más nyelvjárása miatt, részben a média hatására. Vajon kinek a nyelvhasználatára illik ez 1641ben? A nyomdászéra? Valamelyik Debrecenből származott vagy Debrecenben tanult prédikátoréra? Azt mutatja a futólagos vizsgálódás, hogy nem lesz könnyü dolga annak, aki rá akarja bizonyítani a szerkesztőséget valamelyik korabeli deb-

${ }^{22}$ Kérdőjelesen Fodorik Menyhártnak tulajdonítja H. HuBERT Gabriella 2004, i. m. 257, 458460. Több példa van arra, hogy a nyomdász írt előszót, ajánlást, nevét aláírva. 1641-ben sem keltezés, sem helynév, sem név nincs. 
receni prédikátorra vagy professzorra. Még nehezebb azok helyzete, akik az egész kötetet vagy legalább az elöszót a nyomdásznak akarnák tulajdonítani.

1641-ben a helyesírás eléggé kialakult és következetes. Állandósult példákat találunk: 'Anyaszent-egyház', 'föllyül', 'úgy-mint', 'uyjitfad' stb. Ugyanakkor szinte egymás mellett találunk ellenpéldákat is, mint 'meg és megh', 'Orßag és Orßágh', 'ß. Lelek' és 'Sz. Lelek', 'ßent Lelek' és 'Szent Lélek' stb. Kevés kivétellel mindig nagybetüsek egyes szavak, mint 'Angyal', 'Fölfég', 'Kereßtyén', 'Tabor', 'Varas' stb. Van eltérés a kötet két fele között. Eleinte kisbetüs az 'igíje', 'igídet', majd a kötet további részében ismételten 'Igíje', 'Igídet'. Igen gyakran

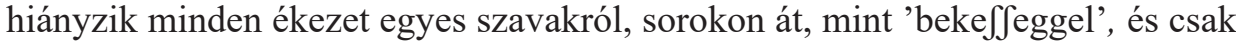
elvétve van 'á', 'é', 'ó', például 'ád vala', 'nád ßállal', 'égben', 'vagyé', 'ßóm-is' stb. Mutatja, mikor az ékezet elszórtan nem hiányzik, hogy például a 'hála' egykori ejtése 'hálá' volt, mint ez a mondat szemlélteti: 'ez Jok jokat hálá-adáfJal és lelki örömmel vegyük tűled'. A kötet második felében a határozott névelő 'az' alakja mellett fölbukkan az 'a' értékben használt 'à' ${ }^{23}$ Gyakori, hogy bizonytalanok a mondathatárok, és eltér elvárásainktól az írásjelek használata. Ismétlődik a kettőspont vagy pontosvessző, ahol a mondat végét várnánk, de ömlik tovább a szöveg, és a folytatás hol kisbetủvel, hol meg nagybetủvel kezdődik. A kötet második felében valamivel gyakoribb a kérdőjel és felkiáltójel. Mindez fölbukkan Rheda idején is, vagy Fodorik más nyomtatványaiban. Olyan lényeges és következetes eltérések alig vannak, amelyekből vitatható szerzőségi kérdéseket eldönthetnénk. Sajnos, az ékezetek hiányától a központozásig, az eddigi vizsgálódás nem kínál igazi fogódzót. Kínál mégis lehetséges kapcsolódást.

Fölbukkan a keleti országrészre jellemző 'í'-zés Margitai Láni Péter (1577?1629) Debrecenben megjelent munkáiban (ő Vizsoly, Huszt, Kálló, Nagybánya prédikátora is volt), bár korántsem olyan mértékben, mint az 1641-es kötetben. Szemléltető különbség, hogy munkáinak a Keresszegi Hermán István gondozta későbbi kiadásait 'ö'-ző, nem 'í'-ző szóalakok jellemzik. Ezzel szemben 1621-ben, Margitainak a Jónás könyvét magyarázó prédikációiban így találjuk:24 'Dicsirjetek', 'dicsiretire', 'dicsiretnek aldozattyanak', 'dicsiretnek Jzavanak', 'dicsiretnek Jzavaval', 'dicsiretnek aldozattyaval' stb. Egy-két ilyen példa is van, mint: 'firfiak', 'firfiu', 'itiletiböl'. Valamint: 'igiret'. Söt a Miatyánkra utalva: 'ne vigyen az kifirtetben'. Nem végig következetes, más alakokkal vegyesen, például: 'iteltek' [= ítélték], 'jo iteletben' stb. Hasonlóan végig nem 'í'-zó az 'igejeböl', 'igek', 'igejenek', 'igekben', 'igejet', 'igeket'. Aztán a Dániel könyvéhez kapcsolódó imádsághoz hasonlóan néha a 'cs' = 'c' hangjelölés is föltünik: 'palcsahoz', 'csikelnek' [= cikkelynek], 'csikkellynek'; máshol mindig 'czikely' írásmód mellett. Korábban a Miatyánkot szintén tagról tagra végig elmagyarázó debreceni kötetben $(1616)^{25}$ hasonlóan van 'dicsiret', 'dicsirlek', 'igireti', ellenben következetesen 'igéket', 'igéknek', 'igéjével' stb. A XII. prédikáció címe: Es ne vigy minket az kifirtetben, etc. Lapokon

\footnotetext{
${ }^{23}$ BÁNFI XVII/2, 2014, i. m. katalógus.

${ }^{24}$ RMNy 1237; a TTREK példánya Rmk 118.

${ }^{25}$ RMNy 1108; a TTREK példánya Rmk 563.
} 
át ismétlődnek a 'kifirtet', 'kifirtetröl', 'kifirtik', 'ne kifirtfed', 'kifirtitek', 'kifirtetik', 'kifirtgetik', 'kifirtö', 'kifirtöt' stb. szóalakok. Nyomatékosan ismételnünk kell, hogy ez nem Fodorik idején kezdődött. Háportoni Forró Pál Curtius-fordításában (1619) ${ }^{26}$ szintén az első lapoktól megjelennek az 'í'-ző szóalakok: 'igik', 'igikkel', valamint 'dicsiretes', 'dicsiretire', 'dicsiretiben', 'dicsiretben', 'dicsiretnek', 'itilem' stb.

Túl a nyelvjárási jellemzőkön, Margitai Láni Péter prédikációinak stílusa, fogalmazása szintén rokon az 1641-es kötet imádságainak tekintélyes részével az állhatatos könyörgés bibliai példáinak szüntelen hangoztatása miatt, különösen a Szentháromsághoz intézve és a Lélek vezetéséért könyörögve. Margitai Láni a prédikátori és esperesi működése során elhangzott könyörgéseket nem füzte a nyomdába adott prédikációkhoz. Gyakorló prédikátorként és esperesként lennie kellett kéziratos, illetve akkor még kéziratban fennmaradt imádságainak. Tanítványának, káplánjának diktálhatott ilyeneket, ezek nyomán másolhatták le könyörgéseit. Az 1641-es kötet imádságainak közel fele keletkezhetett múködéséhez kapcsolódva, eltünt forrásokból átvételként. Ezt az erőteljesen kiütköző vonást jó volna igazolnia a további kutatásnak. Döntő érv, hogy ezek a nyelvi sajátosságok már Rhéda idején nyomtatott munkáiban is megvannak, tehát nem eredhetnek a nyomdásztól, hanem csakis az evidéki szerzőtől.

Egyszerübbnek látszik a kiadó kérdése. Jobb híján nevezte meg H. Hubert Gabriella a debreceni gyülekezetet feltételezhető kiadóként. Debrecen városa megokoltnak látszik. Nem úgy, mint Kolozsvárott, Debrecenben a nyomda városi tulajdon volt, a nyomdász városi alkalmazott, elszámolással tartozott; ezt jól mutatja a szakirodalomban a Csürös Ferenc közlése óta (1911) ismert szerződés 1633-ból, eszerint „,kiváltképpen teológiát az városnak becsületes prédikátori és az becsületes tanács híre nékől kibocsátani nem merészeljen". ${ }^{27}$ A cívisváros kiadási joga tehát vitathatatlan. ${ }^{28} \mathrm{~A}$ város tanácsában nem hagyható ki a számításból a kollégiumi professzorok, a város lelkészei és a szuperintendencia képviselete, ilyen kormányzó testület kötelezte elszámolásra a nyomdászt. Szóbeli egyeztetéssel mindig elintézhettek kiadási kérdéseket ilyen szabályozás alapján, ha pedig volt ilyen ügyekkel kapcsolatos írásbeli anyag, az megsemmisült.

26 RMNy 1174; a TTREK példánya Rmk 789.

27 Csürös Ferenc, A debreceni városi nyomda története 1561-1911, Debrecen, Debrecen Szab. Királyi Város Könyvnyomda-vállalata, 1911, 97-99; BENDA Kálmán, IRINYi Károly, A négyszáz éves debreceni nyomda (1561-1961), Bp., Akadémiai, 1961, 27. számú dokumentum, a város levéltárában örzött kézirat a 32. számú képmellékleten látható.

28 A mindennapi könyörgésről, azaz a Miatyánkról elhangzott prédikációkat (RMNy 1108) Margitai Láni Péter a Debreceni Tanácsnak ajánlotta, név szerint említvén Imre deák főbírót és még két tanácstagot. 
Az imádságok néhány jellemzö vonása

Huszár Gál Komjáti graduálja (1574) arról is nevezetes, hogy közöl szertartási imádságokat, többségében egészen rövideket. Ugyanakkor a hosszabb vagy hoszszú meditációk sem hiányoznak kiadványából. ${ }^{29}$

Az 1641-es kiadásban van egy verses alakú könyörgés, belekerülhetett volna az RMNy énekkezdet-mutatójába, mert sorai nagybetủvel kezdődnek a prózaszedésben: ${ }^{30}$

\author{
Rövid könyörgés az keresztben és kísírtetben \\ Hallgass meg, Uram, kegyessen, \\ Vidámíts meg az keresztben, \\ Ínségemből ments ki engem, \\ Hogy híven azt cselekedjem, \\ Az mi dicsőségedre néz. \\ Minden gonosztúl védelmezz!
}

Rövid, általában egystrófás vers követett a 18-20. századi imádságos könyvek egyik típusában egy-egy imádságot. Verses summák alkották az oktatásban használt Arany ábécé típust. A hagyományos gyülekezetek tagjai templomba lépéskor meghajtott fővel rövid fohászt mondanak, napjainkban sem halt ki ez a szent házat megtisztelő szokás; 30-40 éve is voltak helyek (például Szatmárban, Délvidéken, Abaújban stb.), ahol csoportosan bevonultak vagy kivonultak a templomból, hangosan, kórusban mondtak verses imádságot. Valaki elkezdte, és mindenki folytatta. Az imádság és szokás eredetét legtöbbször nem tudták, megtanulták az öregektől gyermekként. Ilyen kérdésekkel az utóbbi évtizedekben a vallási néprajz foglalkozott, de e munkákban közvetlenül 1641-es kötetünkhöz kapcsolódó adalékot nem sikerült találnom.

Átvétel ez a rövid könyörgés, méghozzá vagy Szenci Molnár Albert Imádságos könyvecskéjéből (1621) közvetlenül, vagy pedig valamilyen közvetett forrásból. Erre a kérdésre is vissza kell még térnünk.

Egyetlen imádságnak van latin felirata, megelőzi a békességért könyörgő imádságot. Rövid, ezért ezt még idézem. ${ }^{31}$

29 Összegyüjtve és mutatózva kiadtam korábban a két Huszár közölte imádságokat, lásd $H u$ szár Gál \& Huszár Dávid, Imádkozó könyv, 1561, 1574, 1577, Debrecen, Református Kollégiumi Nyomda, 2000 (A Debreceni Református Hittudományi Egyetem Gyakorlati Teológiai Tanszékének Tanulmányi Füzetei, 10 - Nyelvi és Művelödéstörténeti Adattár, Kiadványok, 2).

30 1641, 107a. Ugyanez megvan Szenci Molnár Albertnél 1621-ben, erre alább visszatérünk. Az RMNy nem versnek tekintette, az incipit-mutatóban egyik előfordulást sem regisztrálta.

31 1641, 322a. 


\section{Quovis tempore}

Uram, mi rejánk az te szemeid vigyázzanak, s az mi országunkra, és országunknak fejedelmére, s az mi várasunkra, és minden helyben lévő keresztyénekre, szent bölcsességgel, békés szeretettel, és minden szükséges dolgainkban jó szerencsékkel, kegyelmes hozzánk lévén, minket áldj, s ajándékozz.

Kegyelmes hozzánk, etc.

Nem befejezetlen ez az imádság sem, hanem bármikor hozzáadható egy rövid fohászhoz, vagy betoldható más imádság részeként, szintén ismétlődik több toposz a föntebb idézettekben. Láttuk, ilyen panelek közbeillesztése is része volt az egykori gyakorlatnak.

Hosszú imádságok példájaként 1641-ben három, pestises időben mondandó engesztelő könyörgés sorakozik tíz levélen, közöttük a föleg Dániel prófétára alapuló meditáció a leghosszabb az egész kötetben, hét levélre terjed. Ennek nyelvezete is eltér némileg az imádságok zömétől. Forrását szerencsére megnevezhetjük. Kismarjai Veszelin Pálnak a Debrecen városában pusztító tüzvész idején, 1640-ben elmondott 21 prédikációjához ${ }^{32}$ függelék járul, itt jelent meg nyomtatásban ez a hosszú imádság, majd ezt követi néhány ének, köztük a szerző időmértékes sorai. Kötetében is megjelenik az 'í' -zés: 'firfi', 'Igirete', 'igiretek', 'igireti', 'igiretiben', 'itileti', 'itiletid', 'itilheti', 'itilik vala' stb. Gyakori 'cz' helyett a 'cs', még Debreczen helyett is bukkanunk 'Debrecsen' helynévre, egymást érik az ilyen példák: 'csegeres', 'cselō' [= célom], 'csifran', 'Hercsegnek', 'kacsagnak', 'kacsagnának', 'Kacsagvan', 'Kilencsedik', 'orcsádat', 'orcsával', 'piacson-való', 'farcsoltatálit', 'ucsában', 'ucsának' stb. Az imádságok között az említettben ez jelen van, de egyetlen másikra sem jellemző az imádságos énekeskönyvben. Ez az egy imádság tehát átvétel Kismarjai ugyanakkor megjelent kötetéből, akár ő maga a szerző, akár valaki más.

Ezek a megfigyelések késztetnek bennünket a források és a szerkesztő vagy szerző személye tekintetében két állításra. A Debrecenben 1629-1645 között prédikátor Kismarjai Veszelin Pál és az 1630-1641 között prédikátor Keresszegi Hermán István nem lehetett a kötet szerkesztője vagy összegyűjtője. A kötet anyagát összegyüjtő vagy megszerkesztő prédikátort Margitai Láni Péter körében vagy az örökségének gyakorlati végzésében járatos személyek körében kell keresnünk. Erősen korlátozottak ismereteink, például az 1639-1644 között Debrecenben müködő prédikátorról, Váczi Jánosról semmit nem tudunk. Találgathatjuk a kötet célját, erről hallgat az ajánlás, ez lehetett a 17. század elején tapasztalt helyi és országos megpróbáltatások közben magánosan és szertartásosan végzen-

${ }^{32}$ RMNy 1875; a TTREK példánya, amelynek hiányait kézírással pótolták, Rmk 550. Vö. FEKETE Csaba, Magyar Iérusálem, Idömértékes verssorok egy prédikációs kötetben $=A$ Debreceni Déri Múzeum Évkönyve, Annales Musaei Debrecinensis de Friderico Déri nominati, 1980, Debrecen, 1982 (A Déri Múzeum kiadványai, 61), 427-441. 
dő könyörgések ápolása, segítőanyaggal való ellátása. Ez végig jelen van Margitai Láni Péter életmüvében és a névtelen sajtó alá rendező ismereteiben. Ezekre a széles körü ismeretekre mutat rá a következő néhány megjegyzés.

Igen hangsúlyos szakasza az 1641-es kiadványnak négy hitvallás. Az imádságok trinitárius hitvallás-cikkelyeket visszhangoznak a bekezdések többségében, bibliai utalások és parafrázisok mellett. A stílus és a nyelvezet egyaránt ugyanazt tükrözi, ami a kiválasztott énekekben is megjelenik. A föntebb idézett imádságban például 1641-ben az van, hogy „ez világra az te képedre teremtettél”; viszont az 1621-es kéziratban az, hogy „ez világra az te személyedre teremtöttel”. Egyezik a kéziratos változattal az egyik (alig rímelő, a Szentháromság személyeihez intézett) 1569 előtt keletkezett ének részlete, amelyben ugyancsak így van: „,mert ő minket személyére teremte, ékesíte". ${ }^{33}$ Erről az előtünő koncepcióról akkor mondhatnánk bizonyosabbat, ha ismernénk a szerkesztő személyét, tanultságát, nézeteit, könyvtárát. A reformáció első két évszázadának szemlélete imádságok tekintetében sem azonos mindenben a későbbivel, illetve a maival. Mutatja ezt, többek között, hogy imádságnak számítottak a hitvallások, az 'én ezt hiszem és vallom' jegyében. Erre figyelmeztető példa a magyar Niceanum és a Te Deum laudamus.

Huszár Gálnál a Niceai Hitvallás megtalálható a reggeli szertartás anyagában hangjegyesen. ${ }^{34}$ Ünnepen, úrvacsorás szertartásban a gregorián tónus szerint szólt, aztán eltűnt a 17. század második felétől. Mondhatjuk, mindmáig. Közel fél évszázada ugyan elfogadták hazánk történelmi egyházai új ökumenikus fordítását, benne van a 2021-es új református énekeskönyvben, udvariasságból szokták közölni ökumenikus rendezvényeken, ennek ellenére a református szertartásban ismeretlen. Latinul megmaradt a prédikátorok vizsgai és szentelési szertartásán, talán még a 18. században is. 1641-ben megjelent nyomtatásban, tehát használata a 17. században még nem szünt meg. Huszár Gál imádságot is közölt hozzá. ${ }^{35}$ Athanasius hitvallását is recitálták gregorián tónus szerint, erre a graduálokban van bizonyság, nem csupán közlik, mindenütt ott vannak a kézírásos neumák Huszár Gálnál és az Öreg graduálban a nyomtatott szövegsorok fölött.

A Niceanum magyarsága futólagos összehasonlításban is jobb, teljesebb 1641-ben, mint amit Huszár Gálnál találunk, ahol sajtóhibára is gyanakodhatunk, vagy hibás kéziratos forrásra. Az is lehet, hogy a 16. században sem egyetlen fordításban volt használatos nálunk, de az is, hogy a nehézkesebb, vélhetóen akár a reformációnál korábbi nyelvezetủ változathoz képest a 17. századra kialakult újabb magyarítása. Egyelőre annak örülhetünk, hogy ez az eddig ismeretlen példa gazdagítja hitvalló és kegyességtörténeti ismereteinket.

A 18. század tájától hiányzik a mai református köztudatból, így a szertartási életből is a Te Deum. Egykor Ágoston és Ambrus doktor közös hitvallásaként

33 1641, 46b; Jer, dicsirjük mindnyájan Urunkat az Atya Istent. RPHA 0643.

${ }^{34}$ RMNy 353, 88b-92a.

${ }_{35}$ Felirata: Ez igaz hütnek vallása szerént az Istennek keresztyén módra való segitségül hivása. RMNy 353, 92a. 
méltatták. Az 1641-es szöveg teljesen egyezik azzal, amit például a Ráday graduálban találunk, természetesen hangjegyesen. Ebböl az is következik, hogy az András-templom akkori (majd a labancok által 1705-ben szétszaggatott, végül az 1802-es tủzvészben elpusztult) graduálja (graduáljai) a Batthyány-Óvári-Ráday testvér-graduálok hagyományához tartoztak. Ha kideríthetnénk, hogy máshol történt a gyüjtés és/vagy szerkesztés, nem Debrecenben, akkor az ott elérhető kéziratos graduál volt a forrás.

Tehát a kéziratosság ismételten hangsúlyos. Nem az Öreg graduál nyomtatott változata, hanem a kézírásos graduáloké jelent meg 1641-ben. Erre máskor is van példa. Kecskemét és Nagykőrös egyaránt kapott az erdélyi fejedelemtől az Öreg graduálból, de mikor az egyik sérült vagy kiszakított lapjait pótolták, nem az elérhető nyomtatott példányból, hanem egyik részben eltérő szövegü kéziratból másolták le a hiányt.

\section{Szerkezeti eltérések}

Van különbség az 1641-es kötet első felében található és a második felében sorakozó imádságok között. Nem lehetetlen, hogy a háttérben már elindult az örökölt hazai liturgia, gyakorlat és értelmezés elleni hadjárat, ez részben válasz az ellenreformációs törekvésekre, később egyes puritánok szélsőséges irányát is jellemezte. Hangsúlyoznunk kell, hogy polemikus hang sehol nem jelenik meg az imádságokban, az ajánlásról nem is szólva. Ott sem, ahol esetleg ezt természetesnek találhatnánk, ilyen a hamis tanítók és hamis tanok elhárításáról szóló két könyörgés. Igazoló adat hiányában nem mondhatunk semmi biztosat arról sem, hogy esetleg az irénikus irány, David Pareus hatása nincs-e a háttérben. A kötet két felének a sejthető határvonalát nagyjából a Tízparancsolat két táblájához füződő imádság után, tehát az úgynevezett katekizmusi szakasz után vonhatjuk meg.

Többször bonyolultabb, betoldásokkal teli a mondatok szerkezete, régies a felépítése, némelykor meglepő a fogalmazás a kötet második felének néhány imádságában. Arra mutatnak a jelek, hogy a szélesebb körben és huzamosan használt imádságok fogalmazása tisztul, rövidül. A nehézkesebb felépítésủek tehát a kevésbé elterjedtekhez sorolhatók. Gyakoribbnak látszik néhol a 16-17. század stílusára általában jellemző paratagma-készlet (hasonló értelmü szópár) is, mint 'meg gondoltuk' és 'buzgósággal meg eszméllettük', 'nevekedik' és 'öregbül', 'ítélet' és 'szentencia', 'ocsmányul' és 'fajtalanul', 'fortélyoz' és 'csal', 'csintalanság' és 'szilajság', 'elementom' és 'éltető dolog' stb. Az efféle eltérések egyben bizonyítják, hogy az összegyüjtő nem írta át, nem egységesítette kötete anyagát, úgy hagyta, ahogy találta.

Az imádságok néhány szerkezeti eleme csak a kötet első felében található, később nem; ezek is a reformáció évszázadából maradtak. Ilyen például az, hogy Melius Juhász Péternél a keresztség, úrvacsora és a házasságkötés szertartását befejező áldásnak az „Ábrahámnak, Izsáknak, Jákóbnak Istene” a kezdő szavai. 1641-ben ez is föltünik több imádságban - Paksinál szintén -, megtoldva azzal, 
hogy „és nekünk is”. Hálaadó és magasztaló motívumok után gyakori volt a „Viszontag kérjük" kezdetủ új szakaszkezdet. Hasonló a lezáró rész bevezetéseként az „Így tégy mivelünk” indítás. Túlzás nélkül vélhetjük ezekből, hogy az imádságok legalább fele, hasonló vagy azonos alakban a reformáció századában már kialakult és szélesebb körben terjedt.

Nincs elöre eldöntött és végig szorosan követett szerkezete a gyüjteménynek. Laza kapcsolódást, de egyezést nem képzelhetünk Szenci Molnár már említett Imádságos könyvecskéjével. H. Hubert Gabriella észrevette, hogy a gyülekezeti énekeskönyv 1600-as évek táján már fö vonalakban kialakult debreceni típusára hasonlít a szerkezet. De használta, ismerte a gyüjtő a löcsei és kolozsvári énekeskönyveket is, valószínúleg számunkra ismeretlen egyéb források mellett. Biztosra vehetjük, hogy nem az énekekhez keresett, még kevésbé írt imádságokat a gyüjtő. Mutatja ezt, hogy van, ahol egyetlen imádságot követ több ének, máskor pedig több imádságot tartalmazó szakasz után csupán egyetlen éneket talált alkalmasnak. A halottas énekcsoporthoz pedig egyetlen imádság sem tartozik, liturgikus célzás sem, hogy mely énekek voltak szokásosak háznál, melyek temetőben. Az eszerint tagolódó imádságokat vagy nem gyüjtötte, vagy a beteg melletti, a halálra készülők által mondott és a feltámadást váró imádságokat nem tartotta illőnek a kötet megalkotója.

Öt hálaadó imádság alkot önálló szakaszt az úrvacsorai szertartás után, aztán egyetlen ének következik. A gyüjteményben egyedüli módon ezután, kétféle Miatyánk-parafrázis kíséretében, még egy hatodik hálaadó imádságot találunk, ez a 103. zsoltárra és Pál apostol római levelére épül. ${ }^{36}$ Szenci Molnár Albert közölte 1612-ben, kiadva az Oppenheimi Biblia tartozékaként Pfalz református fejedelemségének rendtartását, benne ezt az imádságot. Módosítva megvan az 1929-es, Ravasz-féle Istentiszteleti rendtartásban, azaz máig ismert. Az 1641-es kiadásban az egyik bibliai verset elhagyva, szórendi módosításokkal találjuk, ez kéziratos terjedésre utalhat. Az idézett bibliai zsoltár verseinek mindegyike külön bekezdést alkot. Ugyanakkor a Pál apostoltól idézett részletek nem. Ugyanez az imádság egyetlen bekezdés, többek között a Pataki Ágendában (1658) vagy Szenci Molnárnál a Pfalzi Agendában. 1621-ben viszont ugyanígy tagolva találjuk Szenci Molnár Albert Imádságos könyvecskéjében, és ott a szöveg hiánytalan. Ideje, hogy a korábbi utalások nyomán külön foglalkozzunk zsoltárköltőnk és az 1641-es imádságos énekeskönyv kapcsolatával.

\section{Szenci Molnár Albert példája}

Hitvallásokat zsoltárköltőnk is beiktatott az imádságok sorába, Tria Symbola öszszegző címmel közölte az Apostolicum, a Niceanum és az Athanasianum szövegét. Hat rendbe tagolt munkája a mindennapi könyörgésektől indul el, majd különféle foglalkozásúak, hivatásúak, aztán szertartásokon és a magánéletben,

36 Zsolt 103,1-5a, 8-10. Róm 5,9-10; 8,32. 
valamint az üdvtörténeti ünnepek mellett a sajátos élethelyzetekben alkalmas imádságok közé beiktatott genfi zsoltárokat és más énekek sorát. Müfaját tekintve így beleillik az 'imádságos énekeskönyvek' sorába. Ennél fontosabb, hogy hozzájárult az 1641-ben megjelent mü tartalmi gazdagításához. Szó szerinti átvételeket jelent ez, többször eltérő feliratokkal vagy címekkel. Sehol nem közli azonban a margón sorakozó bibliai hivatkozásokat. Nem követi a szerkezetet sem, amelyben többször vannak visszautalások, és egyes imádságok valamelyik rendbe sorolása nem egészen következetes. 1621-ben az imádságok megnevezése a tartalomjegyzékben sem mindig azonos azzal, amit az illető imádság előtt olvasunk. Eltér az átvett imádságok helyesírása, nem 'í'-ző szóalakokat tartalmaz. Lássuk felsorolásukat! Azonosításukhoz az alábbi táblázat utolsó oszlopában megadtuk a tanulmány végén közölt Mutató szakaszszámát is.

\begin{tabular}{|c|c|c|}
\hline Felirat & $\begin{array}{c}1621 \\
\text { lapszám }\end{array}$ & $\begin{array}{c}\text { Szakasz } \\
\text { sorszáma }\end{array}$ \\
\hline Más [imádság feltámadásért] ${ }^{37}$ & $117-118$ & $=18=$ \\
\hline Más [imádság Szentlélekért] ${ }^{38}$ & $143-144$ & $=20=$ \\
\hline Imádság gyermek keresztelésekor & 220 & $=27=$ \\
\hline Imádság gyermek keresztelés után & 221 & $=27=$ \\
\hline $\begin{array}{l}\text { Könyörgés az keresztségröl való megemlékezésünk- } \\
\text { ben }\end{array}$ & 222 & $=27=$ \\
\hline $\begin{array}{l}\text { Meg vallása az bününknek és könyörgés azoknak } \\
\text { meg bocsátásájért az Úr Vacsorájának osztogatása } \\
\text { elött, és isteni félelem szerint való életnek meg } \\
\text { nyeréséjért }\end{array}$ & $71-73$ & $=29=$ \\
\hline $\begin{array}{l}\text { Meg emlékezés, hálá-adás és könyörgés az szent } \\
\text { vacsora után }\end{array}$ & $224-225$ & $=30=$ \\
\hline $\begin{array}{l}\text { Más formája az hálá-adásnak, ugyan azon Szent } \\
\text { Vacsora után }\end{array}$ & $226-227$ & $=31=$ \\
\hline 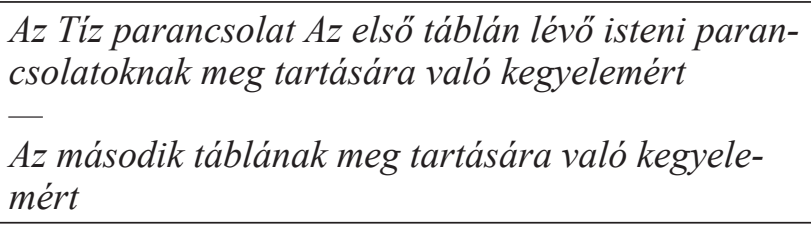 & $53-57$ & $=32=$ \\
\hline $\begin{array}{l}\text { Imádság az Úr Istenhez részegség és tisztátalanság } \\
\text { ellen }\end{array}$ & 295-299 & $=34=$ \\
\hline Keresztyéni alázatosságért való könyörgés & $301-303$ & $=34=$ \\
\hline
\end{tabular}

37 1621-ben más a cím: Húsvét, Kristus Feltámadása.

38 1621-ben más a cím: Imádság a Sz. Lélek Istenhöz, és annak megírása. 


\begin{tabular}{|l|c|c|}
\hline Felirat & $\begin{array}{c}\text { 1621 } \\
\text { lapszám }\end{array}$ & $\begin{array}{c}\text { Szakasz } \\
\text { sorszáma }\end{array}$ \\
\hline Keresztyéni igaz örömért & $303-304$ & $=34=$ \\
\hline Házas férfiúnak könyörgése & 96 & $=36=$ \\
\hline Házas asszonyi-állatnak könyörgése & $97-98$ & $=36=$ \\
\hline $\begin{array}{l}\text { Mind az két házas személynek egy-aránt való } \\
\text { imádsága }\end{array}$ & $98-99$ & $=36=$ \\
\hline Rövid könyörgés az keresztben és kísírtetben & 261 & $=42=$ \\
\hline Segítségért az keresztben és nyomorúságban & 268 & $=42=$ \\
\hline Vigasztalás az keresztben & $267-268$ & $=43=$ \\
\hline $\begin{array}{l}\text { Imádság égi háborúban és ártalmas zúr-zavar } \\
\text { idöben }\end{array}$ & $289-291$ & $=46=$ \\
\hline Drágaságban és halálos idöben ${ }^{39}$ & $208-211$ & $=50=$ \\
\hline $\begin{array}{l}\text { Imádság ez világ végezetinek és az utolsó itíletnek } \\
\text { meg gondoltjáert }\end{array}$ & $\begin{array}{c}315-316 \\
\text { Elias } \\
\text { Hutter }\end{array}$ & $=52=$ \\
\hline
\end{tabular}

Jelenleg nincs magyarázatunk arra, hogy miért éppen ezek és csak ezek az imádságok alkotják részét az 1641-es gyüjteménynek. Közöttük nincs egy sem Ágostontól, Kálvintól vagy a kötetet alkotó neves szerzőktől. Két imádságban is szó van az üldözött keresztyénségről és a törökröl, a hazai helyzet ellenére nem kerültek bele az 1641-es gyüjteménybe. Szó szerinti az átvétel, kivéve a szóalakok, helyesírás és nyelvjárás már korábban említett eltérését.

„Sajnos 1621. évi megjelenése után méltatlanul elfeledték e művét” - jegyezte meg P. Vásárhelyi Judit Szenci Molnár Albert Imádságos könyvecskéjéről, miután a mủvet eleddig legalaposabban feltárta a hasonmás kiadás kísérő tanulmányában, megemlítve a közelkorú, 1645-ben megjelent Janson-féle Biblia (RMNy 2091), a Németalföldi Hitvallás 1650-ben megjelent fordítása (RMNy 2304) függelékében újraközölt néhány könyörgést. ${ }^{4}$ Értékelése a kolozsvári szemelvényes és átírt kiadással ${ }^{42}$ hasonlítva még súlyosabb. Úgy kell-e látnunk ezután is, hogy

39 1621-ben a cím hosszabb, bibliai utalást is tartalmaz: szedetett az Szent írásból Deut. 28.10. I. Reg. 8. Dan. 9. Nehem 9. es az Soltarokból Henric Bullinger és Rod. Gualter által.

40 1621-ben a cím hosszabb, bibliai utalást is tartalmaz: mellyröl emlékezet vagyon Sz. Matth. 13. cap.

${ }^{4}$ Szenci Molnár Albert, Imádságos könyvecske, [Kísérő tanulmány], Bp., Balassi-MTA Irodalomtudományi Intézete-OSZK, 2002, (BHA XXXV), 37.

42 Szenci Molnár Albert, Imádságos könyvecske, s. a. r. P. Vásárhelyi Judit, Kolozsvár, Koinonia, 1999. 
Szenci Molnár müvének hatása a református imádságok történetében már a maga korában sem igazán érvényesült?

Az itt előtártak szerint az 1641-es imádságos énekeskönyv mintegy ötödrésze közvetlenül kapcsolódik Szenci Molnár Albert életmúvéhez, az éppen négyszáz esztendeje megjelent Imádságos könyvecskéhez.

Ösztönzi mindez a további kitartó kutatást, hogy megmondhassuk, ki lehetett az 1641-es kötet önálló koncepciójának megformálója, hogyan kapcsolódik a hajdani örökséghez és a reformáció korának mindennapos gyakorlatához az 1641-es imádságos énekeskönyv. Minden bizonnyal e vidéki gyakorló prédikátor és teológus volt a névtelen, aki gyüjtötte vagy sajtó alá rendezte az imádságos énekeskönyvek terjedelmében és tartalmában kiemelkedő debreceni opusát.

\section{Befejezésül}

Várható, hogy az imádságok többségéhez nem sikerül feltárnia olyan kapcsolatokat, pontos körülményeket és forrásokat a későbbi kutatásnak, amelyeket néhány példában láttunk. ${ }^{43}$ Azonos vonások mellett a stílusbeli különbözőségek arra mutatnak, hogy sokrétủ napi gyakorlat övezte a szabad királyi városok és a református iskolahálózat imádságos életét a három részre szakadt hazában. Óvatosan körvonalazhatjuk talán később, hogy az 1641-es kötetben megjelent imádságok választéka elsősorban a debreceni András-templom és a plébánia egykori könyveire, irattárára és liturgikus kézirataira alapult, vagy ugyanakkor inkább a tágabb egyházvidék prédikátorainak könyveire, kézirataira, beleértve főlleg Váradot, de nem mellőzve a keleti országrész mezővárosait sem.

Kérdezzük meg, vajon miért nem elégedett meg énekek valamilyen gyüjteményével vagy válogatásával az 1641-es szerkesztő? Mi szükség volt arra, hogy szakaszokat alkosson egy vagy több imádságból? Vagy az imádságok felől megközelítve, miért nem imádságos könyvet rendezett sajtó alá? A sok ismeretlen körülmény miatt aligha adódik kész, főként végleges válasz e református müfaj legterjedelmesebb és összetettségében a hasonló kiadványokat jócskán felülhaladó képviselője körül felmerülö kérdésekre.

43 Megköszönöm Bajáki Ritának, hogy az imádságok adatbázisa alapján felhívta figyelmemet további lehetséges kapcsolatokra. Feltünő hasonlóságok vannak egyes imádságokban a Rimaikódexben találhatókhoz, így a Gratiarum actio szövegével, vö. a kódex kiadását http://real.mtak. hu/33236/1/01_bajaki.pdf. A háttérben ismeretlen 16. századi nyomtatott mü lehet. Továbbá az Arany tömjénezö (https://library.hungaricana.hu/hu/view/ RMK_I_1641/ ?pg=48\&layout=r) és a SIDERIUs János, Kisded gyermekeknek való katekizmus, azaz rövid kérdések és feleletek által való tanítás a keresztyéni hitnek fó ágazatiról, Lőcse, 1662 egyes imádságai azonosak. Be kellett látnom, hogy mindezeket több területen folytatott kutatással lehetne esetleg tisztázni. Például feltáratlan, hogy ki és miért változtatta meg a későbbi kiadásokban a Siderius-kátéban közölt imádságokat, és milyen forrásokból dolgozott például Paksi K. György. Jelen pillanatban így ezekröl lemondtam. 
Gyaníthatjuk, hogy valláslélektani és szertartási okokat rejt a talányos gyüjtemény. Kötött és kötetlen, mértékelt és szabad megnyilvánulás ellentétes egységét. Igen hasonló az énekek és az imádságok nyelvezete. Az ének formája kötött, a sor, szótagszám, rím, dallam szabályai miatt. Az imádság kötetlen, akkor is, ha vannak kialakult fordulatai, elvárt elemei, ilyen például a lezáró háromságos doxológia. Régen hangos szóval imádkoztak, és beszédüknek volt lejtése. A mai közbeszédhez képest dallamosabb. Gyermekek - pedagógusok bosszúságára - ösztönösen felviszik hangjukat, mikor nem kellene, alakítják a beszéd dallamát. Ha nem hadarás vagy motyogás a közösség imádkozása, a beszéd dallama átminősülhet dallamos beszéddé, mint a jó mesemondóé. Innen már csupán egyetlen lépés valamilyen imatónus alkalmazása, ezt jelenlegi kultúránkban inkább éneklésnek tekintjük, de a régi világban ez illendő megszólaltatásnak számított, és a hajdani Kelet öröksége jórészt meg is maradt a latin szertartás énekbeszédében. Ilyen nekifohászkodás elözi meg a hosszú, bibliai históriákat, amelyek ugyanazt mondják, de másként. Az imádság nem közönséges beszéd. Illik az éneklés elé vagy mellé.

Mutatja ez a néhány eddig felderített kapcsolat, hogy szóbeliség és írásbeliség láthatatlan hálója vette körül a nyomtatásban megjelent munkákat. Fejből tudtak, fiatalon vagy gyermekként megtanultak a régiek sok imádságot, később emlékezetből írták le, vagy diákjaiknak diktálták fejből. A kéziratos gyüjtemények öszszeírása mellett kötetek üres lapjaira, nyomtatványokhoz köttetett levelekre, ívekre is írtak vagy másoltak imádságokat. Forrásaikat igen gyakran nem árulták el. Az imádságok széles körü összegyüjtésére érthetően nem történt eddig kísérlet, ${ }^{44}$ de ha erre ma van is törekvés, nem számolhatunk az elhasználódott vagy elpusztult nyomtatványok példányainak kéziratos toldalékaival. Ezért becses minden aprócska adalék, amely valamelyes világosságot vet erre a háttérre.

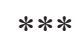

\section{Mutató}

Az RMNy 1874 leírásában az imádságoknak nincs mutatója. Alább a kezdőszavak után néhány jellegzetes szószerkezet, nem teljes mondat következik, két vagy három sorban, hogy a kutató, ha rábukkan az imádságra, lehetőleg ráismerjen. A nyomtatvány eredeti szakaszbeosztása, amelyet az RMNy 1874 leírása is tükröz, római számmal szerepel a mostani arab számos jelölése után. Ez mutatja a használónak a különbségeket és az összefüggést. A hosszabb imádságoknak nemcsak az első, hanem további bekezdéseiből is szerepelnek jellegzetes szavak, fordulatok. Az egyazon szakaszba tartozó imádságokat * választja el. Ha az imádság belső

${ }^{44}$ Kivétel a Pázmány Péter Katolikus Egyetem kezdeményezése, az MTA-PPKE Barokk Irodalom és Lelkiség Kutatócsoportban folyó ima-adatbázis építése (távlatban a mutatózáshoz szövegkiadás is járul majd): Az 1800 előtti magyarországi imádságok adatbázisa, http://ima.btk.ppke.hu/. 
címmel tagolódik, akkor nincs újabb lapszám, gondolatjel mutatja az elválasztás helyét, nem csillag. Határuk az utánuk következő egy vagy több ének, ezek incipitjét az RMNy 1874 tartalmazza.

Mennynek és földnek Ura, Istene! Hálát adok... veszedelemtül meg óltalmaztál... angyalid légyenek én vélem...

Más [ reggeli imádság ] $(1 \mathrm{~b}-\mathrm{A} 8 \mathrm{~b})$

Örök, mindenható, kegyelmes Úr Isten... képedre teremtettél... békeséggel virrasztottál... viszontag könyörgünk... Adjad az te Szent Lelkedet... ótalmazz meg... hírtelen haláltúl... kétségben való eséstül...

Más, kivált képpen való könyörgés $(2 \mathrm{~b}-\mathrm{B} 1 \mathrm{~b})$

Minden irgalmasságnak és kegyelmességnek Istene... Hálákat adunk... ez mái napnak világosságára juttattál... Viszontag... hallgasd meg az szegény kórokat... véghetetlen kegyelmességed... jó vóltod szerint...

Más könyörgés, melyet mind reggel s mind estve mondhatni $(5 \mathrm{~b}-\mathrm{B} 4 \mathrm{~b})$

Úr Isten, mi kegyelmes szerelmes és szent Atyánk! Ki minden állatoknak... tápláló Atyja vagy... hálákat adunk... oltalmazásodért...

$$
\text { * }
$$

$$
=2=
$$

Estvéli imádság $(10 \mathrm{~b}-\mathrm{B} 9 \mathrm{~b})$

Hálákat adunk te néked mi mennyei szent Atyánk, hogy... az ördögnek álnakságátúl... meg örizvén... lelki kenyérrel is tápláltál...

$$
=3=
$$

(II)

\section{Úton járónak való imádság $(12 \mathrm{~b}-\mathrm{C} 1 \mathrm{~b})$}

Ó, emberi nemnek igaz örizője... kinek örizése nélkül senki bátorsággal nem járhat... utat mutattál az Ábrahám szolgájának... Tóbiás fiának is...

Más [imádság útra indulónak] (13a - C2a)

Mindenható Úr Isten, én mennyei szerelmes szent Atyám... útra el indulok... Tóbiás... Rafáel angyaltúl vezéreltetett... vissza hozattatott... 
Uram Isten, mi mennyei szerelmes szent Atyánk ... intettél, hogy... vigyázzunk... hivatalunkban... vigyázva találtassunk...

\section{$=5=$ \\ (IV) \\ Gazdagsággal jól élésért (23b - D4b)}

Úr Isten, mi mennyei szerelmes szent Atyánk... adjad... ajándékiddal jól élhessünk... vezérljed az mi lelkünket...

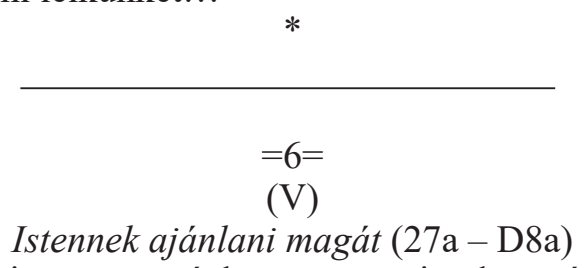

Én Uram, Istenem, ki az mennyégben vagy... irgalmasságodnak... ajánlom... elmémet, szóllásomat, bé menetelemet...

(VI)

Istennek jó téteményiért $(30 \mathrm{~b}-\mathrm{E} 1 \mathrm{~b})$

Hálákat adok néked én Uram Istenem... méltóztattál... képedre... teremteni... Fiadnak vérével... fogadott fiaddá tenni... éltetni...

$$
\begin{gathered}
=8= \\
\text { (VII) }
\end{gathered}
$$

\section{Lelki testi jókért $(38 \mathrm{~b}-\mathrm{F} 1 \mathrm{~b})$}

Úr Isten, mi kegyelmes, szerelmes szent Atyánk... Fiad által nékünk meg igírted... oltalmazz meg az ördög... csalárd tudományátúl... 
Ó, egy Istenségnek állatjában való Szent Háromság... Ki lakozol az... meg foghatatlan világosságban... bírod ez világnak kerekségét...

$$
=10=
$$

(IX)

Az apostoloknak és egyéb Szent Írás magyarázó doktoroknak vallás-tételek az

$$
\text { Szent Háromságról }(48 \mathrm{~b}-\mathrm{G} 1 \mathrm{~b})
$$

Symbolum Apostolicum (49a- G2a)

Hiszek egy Istenben, Mindenható Atyában... és Jézus Kristusban... ki fogontaték Szent Lélektül... szálla alá poklokra...

\section{Symbolum Niceanum $(46 \mathrm{~b}-\mathrm{G} 2 \mathrm{~b})$}

Hiszek egy Istenben, mindenható Atyában... látható és láthatatlan állatoknak teremtőjében... Kristusban... ki által mindenek löttenek...

\section{Symbolum sancti Athanasii (50b - G3a)}

Valaki akar idvözülni... tudja az közönséges keresztyéni hitet: melyet... meg nem tart... örökre el vész... Szent Háromságot az egységben tiszteljünk... azoknak állatját meg se szaggassuk...

\section{Symbolum Sancti Ambrosii et Augustini (53b - G6b)}

Téged, Isten, dicsírünk... minden földi állat tisztel... kerúbín és szeráfín angyalok szüntelen szóval dicsírnek... Teljes menny-ország... szentségednek dicsőségével...

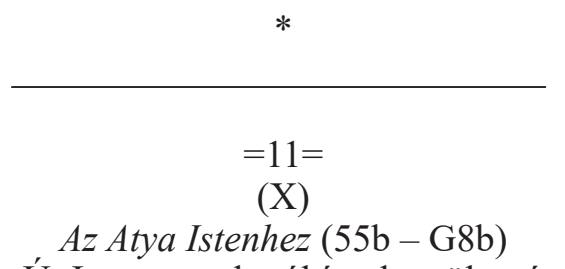

Örök mindenható Atya Úr Isten... az kerúbímokon ülsz, és az mélységeket nézelled... Te vagy Ábrahámnak, Izsáknak és Jákóbnak kegyelmes Istene... keresztyéneknek igaz és irgalmas Istene... 


$$
\begin{gathered}
=12= \\
\text { (XI) }
\end{gathered}
$$

Az Fiú Istenhez (58a - H3a)

Uram, Jézus Kristus, ... mi édes... oltalmazónk... siketeket, sántákat, bél-poklosokat meg gyógyítottál, segílj meg minket szegény juhaidat...

$$
\text { * }
$$

$$
=13=
$$

(XII)

$$
\text { Az Szent Lélek Istenhez (62a - H7a) }
$$

Uram, Szent Lélek Úr Isten, ki egyenlő, egy állatú... mindkettőtül egyenlőképpen származván, meg mondhatatlanúl... tanítványira penig tüzes nyelveknek képében szállottál...

$$
\text { Más [imádság a Szent Lélekhez] (63a - H8a) }
$$

Jövel Szent Lélek Úr Isten! Töltsd bé... mennyei ajándékoknak osztogatója... lelkünknek igazgatója, vigasztalója és édes vendége...

Más [imádság a Szent Lélekhez] (63b - H8b)

Ó, szenteknek drága záloga Szent Lélek... tisztítsd... homályosíttatott lelki szemeinket... minden gonosz kívánságot... égess ki az mi tagainkból...

$$
\begin{aligned}
& =14= \\
& \text { (XIII) }
\end{aligned}
$$

Kristus isméretiért és az benne való hitért (67b - I2b)

Úr Isten, mi szerelmes szent Atyánk! Ki meg tekintéd... nyavalyás az mi nyavalyás voltunkat, és pásztorúl és tanítóúl adtad... igíjével legeltessen... örökös fiaiddá tégyen...

\section{Más [imádság Kristusban való hitért] (68a - I3a)}

Úr Isten! Hálákat adunk... bünös embereket... isméretedre hoztál... teljes lélekkel higgyünk... az ő benne való hit által idvözülhessünk...

$$
=15=
$$

(XIV)

Kristus testben meg jelenéséjért $(75 \mathrm{~b}-\mathrm{K} 2 \mathrm{~b})$

Uram Isten, mi kegyelmes... egy szülött Fiadat ez világra el bocsátottad... az mezőn lévő pásztoroknak meg parancsoltad, hogy ne féljenek... 
Más [hálaadás Kristusért] (76a-K3a)

Úr Isten, mi mennyei szent Atyánk... Fiadat ez világnak ki jelentetted... hogy minékünk lenne bölcsességünk, igazságunk, szentségünk, világosságunk...

\section{$=16=$ \\ (XV)}

Kristus környül-metélkedéséjért (94b - M3b)

Kegyelmes Atya, mindenható... az szegény bünösöket nem utálád,... Fiadat az törvény alá vetetted, hogy... haragodat meg engesztelnéje...

$$
=17=
$$

(XVI)

Krisztus kin-szenvedéséröl és haláláról (99a-M8a)

Hálákat adok te néked... Kristus... igaz Isten és igaz ember... érdemem nélkül... az örök veszedelemből meg váltottál...

\section{(XVII)}

Más [hálá-adó imádság Kristus haláláért] (100b - M9b)

Légyen néked dicsőség és hálá-adás... engedelmes lévén mind az keresztnek haláláig... az törvént bé töltötte... kétség nélkül hiszem...

$$
\begin{gathered}
=18= \\
(\mathrm{XVIII}) \\
\text { Nagyszombatra }(109 \mathrm{~b}-\mathrm{N7b})
\end{gathered}
$$

Ó, Jézus... Hálát adunk... el is temettettél... koporsónk ne lenne nékünk örökké való tömlöcünk, hanem ideiglen való aluvó szállásunk...

\section{(XIX)}

Krisztus föl támadásáról $(109 \mathrm{~b}-\mathrm{N} 8 \mathrm{~b})$

Uram, Jézus Kristus... Atyádnak ábrázatja vagy,... ki vagy egyenlő istenségben és el változhatatlan természetben... Téged hílak...

Más [imádság feltámadásért] (110b - O1b)

Ó, mindenható örök Isten, ki... Fiadat az halálból föl támasztottad... Adjad, hogy... új életre támadjunk föl. 


$$
=19=
$$

(XX)

Krisztus mennyben föl menéséröl (123a-P4a)

Uram, Jézus... Atyádnak dicsőséges jobbjára ültél... uralkodol mind az földön és égen lévő állatokon... bocsásd el az te Szent Lelkedet, és adj... tudós, bölcs és jámbor egyházi szolgákat...

Uram, Jézus... ez mái napon... az Szent Lelket csudálatosképpen el bocsátottad... adjad nékünk is... mely igazgasson és vezéreljen...

$$
\text { Más [imádság Szentlélekért] (128b - Q1b) }
$$

Ó, dicső Szent Lélek, ki harmadik személye vagy az egy örökké való Istenségnek... az egész keresztyénségtül Szent Léleknek neveztetel...

$$
\begin{gathered}
=21= \\
\text { (XXII) } \\
\text { Templomban menéskor }(136 \mathrm{a}-\mathrm{Q} 9 \mathrm{a})
\end{gathered}
$$

Mindenható Úr Isten... bé megyek az te házadban... örömest lészek jelen az te szentidnek gyülekezetiben...

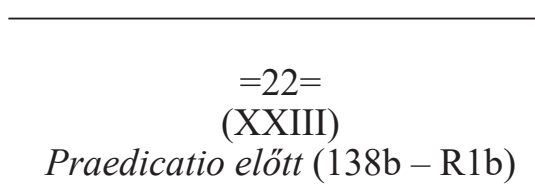

Úr Isten, mi mennyei szerelmes szent Atyánk! Hálákat adunk... hogy az te szent igídet... Fiad által ki nyilatkoztattad...

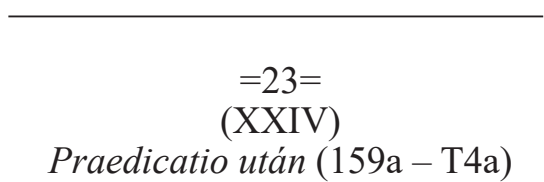

Úr Isten, mi mennyei szent Atyánk! Hálákat adunk... meg éhezett lelkünket tápláltad lelki kenyérrel... gyökereztesd meg az te szent igídet... 
Más [hálaadás prédikálásért] (159b - T4b)

Hálákat adunk néked... szent Atyánk... hogy ez világnak utolsó... állapatjában... bủvön prédikáltattad, mostan is prédikáltatod...

\section{$=24=$ \\ $(\mathrm{XXV})$}

Az Istennek minden lelki testi el vött és el vejendö jovájért való hálá adás és könyörgés (166a - V3a)

Örök mindenható Isten... Ábrahámnak, Izsáknak és Jákóbnak, s minékünk is kegyelmes Istenünk... hasonlatosságodra teremtettél...

$=25=$
$(\mathrm{XXVI})$

Isten igéje hallgatóinak imádsága, mind magokért, s mind penig keresztyén tanitójokért $(172 \mathrm{~b}-\mathrm{V} 9 \mathrm{~b})$

Minden irgalmasságnak és kegyelemnek Istene... minden jóknak kút-feje... taníts... akaratodnak cselekedetire, vivén minket az igaz úton...

Más [imádság a keresztyén tanítókért] (173a - V10a)

Örök mindenható fölséges Úr Isten... Hálákat adunk... Anyaszent-egyházadban... lelki pásztorokat adtál... nagy jó kedvvel hirdetik...

\section{$=26=$ \\ (XXVII)}

Igaz hitben való meg maradásért $(178 \mathrm{~b}-\mathrm{X} 5 \mathrm{~b})$

Kegyes és kegyelmes Atya Úr Isten, szabadíts meg... öregbítsed mi bennünk az igaz hitet... csak te hozzád egyedül ragaszkodván...

$=27=$
$(\mathrm{XXVIII})$
Keresztségért való hálá-adás

Hálát adok néked Uram Jézus Kristus... Atyáddal meg békéltettél, az örök haláltúl, pokoltúl szent halálod érdemével meg váltottál...

\section{(XXIX)}

Imádság gyermek kereszteléskor $(182 \mathrm{~b}-\mathrm{Y} 1 \mathrm{~b})$

Ó, mindenható örök Isten... az víz özönnel az... meg jobbúlatlan világot meg büntetted, és az hívő Nóét nyolcad magával... meg tartottad... 


\section{(XXX)}

Hálá-adás gyermek keresztelés után (183b - Y2b)

Mindenható irgalmas Atya Úr Isten... nékünk és az mi gyermekinknek büneinket meg bocsáttad... egy született Fiadnak tagjaivá töttél...

\section{(XXXI)}

Könyörgés az keresztségröl való meg emlékezésünkben (184b - Y3b)

Ó, mi urunk, Jézus... Hálákat adunk... Isten fiainak száma közé fogadtál... Szent Lelkednek élő vizével meg mosogatsz...

$$
=28=
$$

(XXXII)

Az poenitentiarol. Meg vallása az bününknek és könyörgés azoknak meg bocsátásájért az Úr vacsorájának osztogatása elött, és isteni félelem szerint való életnek meg nyeréséjért $(188 \mathrm{a}-\mathrm{Y} 7 \mathrm{a})$

Én nyavalyás bünös ember, meg vallom... vétkeztem te ellened... parancsolatidat... által hágtam...

Más [bünvalló imádság Úr vacsorája előtt] (191b - Y9b)

Igaz és irgalmas mindenható bölcs Isten... vallást tészek... bünben fogontattam és születtettem... teljes szíből, lélekből nem szerettelek...

$=29=$
$($ XXXIII)
Úr vacsorájakor (200a - Aa1a)

Úr Isten, mi mennyei szent Atyánk... minékünk szent vacsorát szerzettél melyben az ő szent testét és vérét vesszük igaz hitünknek általa...

$$
=30=
$$

(XXXIV)

Meg emlékezés, hálá-adás és könyörgés az szent vacsora után $(206 a-A a 7 a)$

Uram, mindenható Isten... buzgósággal meg eszméllettük... minémü... titok légyen, az melynek meg szentelésivel... mi mostan élünk... 
Más [hálaadás] (207a - Aa8b)

Örök mindenható áldott Úr Isten... nagy hálákat adunk... minden időbeli kegyelmes atyai gondviselésedért... igaz isméretedre juttatál...

$$
\text { Más [imádság] (208b - Aa10b) }
$$

Örök mindenható Isten... hálákat adunk... hogy tennen magadat, az te Anyaszent-egyházadnak ki jelentetted... Kristust ez világra bocsáttad...

Más [imádság] (210b - BB1a)

Hálákat adunk te néked... véghetetlen... nagy szerelmedért... drága árron... az örök haláltúl meg váltottál... meg szenteltél...

$$
\text { Más [háláadás] (211b - Bb2b) }
$$

Hálákat adunk mi te néked... kegyességedért, hogy... az evangéliomnak prédikáltatását és az szent jegyeket... minékünk szerzetted...

$$
\begin{gathered}
=31= \\
(\mathrm{XXXV}) \\
\text { Más formája az hálá-adásnak, ugyan azon Szent Vacsora után } \\
(215 \mathrm{a}-\mathrm{Bb6a})
\end{gathered}
$$

Áldjad én lelkem az Urat... Ki meg szabadítja az koporsóból... életedet... tulajdon fiának sem kedvezett...

$$
\begin{gathered}
\text { (XXXVI) } \\
\text { Miatyánk magyarázatja (213a-Bb7a) }
\end{gathered}
$$

Mi mennyei szerelmes szent Atyánk, szenteltessék meg mi bennünk az te szent neved, hogy vallást tegyünk azzal, és dicsekedjünk...

$$
\text { Más [imádság a Miatyánkbó1] (219a-Cc2a) }
$$

Úr Isten, mi Atyánknak vallunk... teremtettél és meg váltottál... Fiad által... hatalmasnak is vallunk...

$$
\begin{gathered}
* \\
=32= \\
(\text { XXXVII) } \\
\text { Az Tiz parancsolat }(223 \mathrm{a}-\text { Cc6a) }
\end{gathered}
$$

Az elsö táblán lévö isteni parancsolatoknak meg tartására való kegyelemért Ó, mindenható Isten, adjad nékem... hogy én csak te benned higgyek... babonát, bálványozást, el távoztassak... igídet örömest hallgassam... 


\section{A második táblának meg tartására való kegyelemért}

Könyörgök, Uram, te néked, az mi közönséges atyáinkért is, az egyházi szolgákért... fejedelminkért... ne keressék csak az ünnön tisztességeket...

\section{$=33=$ \\ (XXXVIII) \\ Teremtésért való hálá-adás $(231 \mathrm{~b}-\mathrm{Dd} 4 \mathrm{~b})$}

Mindenható Úr Isten... ki mindöröktül fogva voltál... imádlak, magasztallak... igíddel teremtetted, és szépen meg ékesítetted...

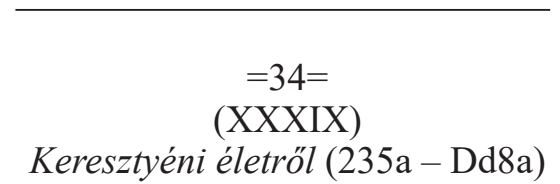

Úr Isten, mi kegyelmes gondviselő Atyánk... igazgasd az mi életünket... te benned való félelemben élhessünk... fegyhetetlenül járhassunk...

\section{(XL)}

Imádság az Úr Istenhez részegség és tisztátalanság ellen (235b - Dd8b) Kegyelmes Úr Isten... teremtettél és engedtél... vidámúlásunkra, az mint az bort is... hogy az embernek szívét meg erősítse...

\section{(XLI)}

Keresztyéni alázatosságért való könyörgés (240a - Ee5a)

Mindenható Úr Isten... az kevély szív utálatos te előtted... elöl-járója az veszedelemnek... adj igaz keresztyéni alázatosságot énnékem...

\section{(XLII)}

\section{Keresztyéni igaz örömért (242a - E7a)}

Ó, kegyelmes Atya Úr Isten!... mondottad, hogy örüljünk... az te orcád előtt... ez világnak átkozott örömeiben részesek ne légyünk...

$$
=35=
$$

(XLIII)

Urak és fejedelmek imádsága $(255 \mathrm{~b}-\mathrm{Gg} 2 \mathrm{~b})$

Mindenható Úr Isten... hatalmadban vannak mind azok, az kiket te fejedelmekké és regnálókká rendelsz... nevednek tisztessége öregbíttessék... 


\section{(XLIV)}

Fejedelmekért és egyéb tisztség-viselökért (256 - Gg3a)

Örök mindenható, fölséges Úr Isten... fejedelminket kegyelmes szemmel nézzed... követhessék minden példájokat... Józsuénak, Gedeonnak, Dávidnak, Ezékiásnak, Józsiásnak, Theodosiusnak...

\section{Más [könyörgés tisztség-viselökért] (257a-Gg4a)}

Úr Isten, ki meg parancsoltad... légyenek te hozzád könyörgések... hálá-adások az királyokért, fejedelmekért... tiszta szívböl könyörgünk...

\section{$=36=$ \\ (XLV)}

Házas férfiúnak könyörgése (260b - Gg7b)

Uram, mindenható... szeressem az én feleségemet, az mint Kristus szerette az ő gyülekezetit... okossággal lakjam...

\section{(XLVI) \\ Házas asszonyi-állatnak könyörgése}

Ó, kegyes Atya Úr Isten... légyek engedelmes az én férjemnek... végyem az hívő Sárának példáját...

\section{(XLVII)}

Mind az két házas személynek egy-aránt való imádsága

Adjad mind kettőnknek... hogy mi az elégséget, mellyet... mi nékünk engedsz, takarékossan tartsuk,... semmit el ne tékozoljunk...

$$
\text { .. semmit el ne tékozol }
$$

$$
=37=
$$

(XLVIII)

Titkos szükség, testi nyavalya, avagy háborúság ellen (264b - Hh1b)

Úr Isten, ki az te itíletedből... nyavalyák alatt akarsz tartani...

$$
\text { Más [imádság könyörületért] (265a - Hh2a) }
$$

Fölséges mindenható kegyelmes Úr Isten... nem kívánod az bünös... halálát, hanem inkább hogy megtérjen és éljen...

\section{Más [imádság vigasztalásért] (265b - Hh2b)}

Úr Isten, mi mennyei szent Atyánk... háborúság alá vetettél... veszélyt... mi rejánk bocsátottál, az bűnnek el távoztatásáért... 
Más [imádság megszabadításért] (266a - Hh3a)

Uralkodó hatalmas Úr Isten! Légy kegyelmes... ments meg az jelenvaló nyomorúságimból az Kristusért... ö érette magasztalni akarsz...

\section{$=38=$ \\ (XLIX)}

Foglyoknak és mártíromoknak imádsága (281a - Ii10a)

Örök mindenható Isten... teremtetted [a] mennyet... bé rekesztetted az mélységeket... én peniglen vétkeztem...

\section{Más [imádság] (282a - Kk1a)}

Mindenható, nagy irgalmú Úr Isten! Ki uralkodol... senki te ellened nem állhat... Könyörgünk tenéked mind azokért, az kik... nyomorgattatnak...

*

Más [imádság] (283b - Kk2b)

Úr Isten, híveknek gond viselóje... méltóztassál... az te angyalidat alá küldeni... győzödelmessen vigyenek te fölségednek széki eleiben...

\section{Más [imádság szenvedésben] (284 - Kk3a)}

Úr Isten, mi mennyei szent Atyánk... meg engedted, hogy... szentid... szenvedjenek, mint az szent István protomartír...

$$
=39=
$$

(L)

Ördög és annak dühössége ellen (286a - Kk5a)

Úr Isten, mi mennyei szent Atyánk... látja szent fölséged, hogy az mi régi ellenségünk, az pokolbéli Sátán, ólálkodik utánnunk...

Más [ imádság ördög ellen ] (286b - Kk5b)

Úr Isten, mi kegyelmes szent Atyánk... hisszük... szent Fiadat azért bocsátottad ez világra, hogy... az gonosz ellenségtúl meg óltalmazzon...

Más [ imádság ördög ellen ] (287a - Kk6a)

Uram, Jézus Kristus, örök mindenható Istennek bölcsessége, és ki metszett ábrázatja... haláloddal meg váltottál... Szent Lelkeddel el jegyeztél... 
Hamis tanitók, az eklézsiának és abban lévő igaz keresztyéni hit vallóinak kegyetlen ellenségi ellen (292b - L13b)

Úr Isten, mi kegyelmes szent Atyánk, hálákat adunk... Igídnek igaz isméretire hoztál... oltalmazd meg... igaz tanítóidat tévelygéstül...

Más [imádság védelmezésért] (293a - L14a)

Ó, Uram Isten, miért zúgolódnak... hamis tudománt plántáljanak az te Eklézsiádban...

Más [imádság megtartásért] (294b - L15b)

Úr Isten, mi mennyei szent Atyánk... érdemljük az büntetést... búsúlásodban ne büntess ennyire az pogányokkal...

*

$$
=41=
$$

(LII)

Kétség ellen való imádság (302b-Mm3b)

Irgalmas Isten... Vallom... magamat bünösnek... parancsolatidat gyakorta, sőt minden szem-pillantásban által hágtam...

Rövid könyörgés az keresztben és kísírtetben (307a-Mm8a) Hallgass meg, Uram, kegyessen, Vidámíts meg az keresztben...

(LIV)

Segitségért az keresztben és nyomorúságban (307a-Mm8a) Ó, Úr Isten... szegény híveidnek segítségére jüj... Ihon, én... nem tudom, hová térjek, és kihez folyamodjam...

$$
=43=
$$

(LV)

Vigasztalás az keresztben $(309 \mathrm{a}-\mathrm{Nn} 2 \mathrm{a})$

Én édes Uram, Istenem, én... el vagyok buríttatván... haragod valamennyire keményen és sanyarúan mutatja nekünk magát... 


$$
=44=
$$

Hadi könyörgés $(312 \mathrm{a}-\mathrm{Nn} 5 \mathrm{a})$

Úr Isten, mi atyáinknak Istene! Lásd... ellenséginknek táborát... az sötétség meg környékezé őket. Ezenképpen legyenek ezek is...

\section{Más [könyörgés hadas időben] (313a - Nn6a)}

Örök, fölséges, mindenható Atya Úr Isten... fölségednek bűnös fiai... vallást tészünk... méltán érdemlettük... ostoridat és büntetésidet...

$$
=45=
$$

(LVII)

Quovis tempore (322a - Oo5a)

Uram, mi rejánk az te szemeid vigyázzanak... jó szerencsékkel, kegyelmes hozzánk lévén, minket áldj, s ajándékozz...

\section{Békeségért (322b-Oo5b)}

Örök Atya, mindenható Úr Isten, ki békeségnek vagy szeretője... az egész keresztyéni társaságot... hadak és vér ontások között... oltalmazd meg...

$$
=46=
$$

(LVIII)

Imádság égi háborúban és ártalmas zúr-zavar időben (325a - Oo8a)

Ó, mindenható Ur Isten, az zsoltárokban való jeles megírásokból...

$$
\text { (LIX) }
$$

Az földi gyümölcsökért (327a- Pp2a)

Örök mindenható Úr Isten... nagy jó voltodból mind az teljes földet meg ékesítetted minden féle szép nevésekkel... kikkel mind az emberek... magokat táplálják...

$$
\begin{aligned}
& =47= \\
& \text { (LX) }
\end{aligned}
$$

Mindennapi táplálásért való imádság (330b - Pp5b)

Mindenható Úr Isten, minden állatoknak gondja-viselője és éltetője... kiáltunk... adj mi nékünk irgalmasságodból minden-napi kenyeret... 
Asztal áldás, avagy étel elött való imádság (337b - Qq2b)

Mindeneknek szemei te rejád néznek... adsz... eledelt alkolmatos időben, és bé töltesz minden állatokat az te áldásoddal...

$*$

Más [imádság étel előtt] (338a-Qq3a)

Örök mindenható... ki mindeneket semmiből teremtettél... ki az Izráel fiait az pusztában mannával,... negyven esztendeig el tartottad...

$$
=49=
$$

(LXII)

Étel után való hálá adás és könyörgés (339a-Qq4a)

Így szól az Úr a Mójzses ötödik könyvének nyolcadik részében: Mikoron ejéndel és megelégedéndel, hálákat adj...

Más [hálá-adó imádság étel után] (340a-Qq5a)

Adjatok hálát az Úrnak, mert jó, és az ő irgalmassága örökké meg maradandó: ki ád eledelt minden testnek, és az holló fiaknak...

\section{Más [imádság étel után] (340b - Qq5b)}

Úr Isten, mi mennyei szent Atyánk, hálákat adunk te néked az te el vött javaidért, melyekkel az mi halandó testünket táplálod...

\section{$=50=$ \\ (LXIII)}

Drágaságban és halálos időben (341a-Q6a)

Mindenható, örök, irgalmas Úr Isten... igídben... orcámat ti ellenetek fordítom... büntetlek... háborús fergeteggel... szélvésszel, hadakkal...

\section{(LXIV)}

Vallástétel és imádság, mely az Dániel könyörgéséből és az Szent Irásnak egynéhány áhitatos lókusiból egyben szedegettetvén, az Úr házában az romlásnak idején, buzgó fohászkodásokkal az hivektül Istenhez emeltetett az Úr haragjának engesztelésére (343a-Q8a)

Jehova, Jehova, seregeknek Istene... méltatlan bünös fiaid és és leányid ez mi mostani siralmas romlásunkban... az Dániel prófétával mind imádkozunk tenéked... tekints kegyelmesen minket... ki megtartod a fogadást és az irgalmasságot azokhoz, akik... meg örizik az te parancsolatidat... 


\section{(LXV) \\ Dög halál ellen (350b - Rr7b)}

Örök, mindenható, élő, igaz... Atyánk, Ur Isten! Valljuk... színednek előtte... bünösök vagyunk... melyekért ez keserves dög-halál rejánk szállott...

\section{$=51=$ \\ (LXVI)}

Bóldogságnak meg nyeréséjért (355a-Ss2a)

Ó, emberi nemzetnek drágalátos váltsága... sebeidért... gyógyítsd meg az én lelkemnek sebeit, és őrizz meg ellened való bünben eséstül, hírtelen és vélhetetlen haláltúl...

$=52=$
(LXVII)
Halálra való vigyázás $(357 \mathrm{a}-\mathrm{Ss} 4 \mathrm{a})$

Úr Isten, mi mennyei szent Atyánk... meg jelentetted... hogy... az mi testünk föl támad a porból... készíthessük magunkat józanságban...

\section{(LXVIII)}

\section{Betegnek imádsága $(387 \mathrm{~b}-\mathrm{Ss} 4 \mathrm{~b})$}

Uram Isten, én kegyelmes gond-viselő A tyám... könyörgök... elégeld meg... betegségemet... erösítsd meg tagaimat...

\section{(LXIX)}

Lelkét Istennek ajánlani $(358 \mathrm{~b}-\mathrm{Ss} 4 \mathrm{~b})$

Örök, mindenható Úr Isten... könyörgök... szükségemnek idején... halálom óráján segélj meg... hogy vígan mehessek te hozzád...

\section{(LXX)}

Az meg halók fölött való imádság (360a - Ss7a)

Mindenható kegyelmes Úr Isten... Kérünk tégedet... emlékezzél meg... atyánkfiáról, ki... igaz hitben és vallásban múlik ki...

\section{Az föl támadásról (360b-Ss7b)}

Úr Isten, mi mennyei szent Atyánk... Fiadat ez világra bocsátottad ezért, hogy... föl támadásának ereje az mi föl támadásunkra is el hathasson...

\section{(LXXI)}

Imádság ez világ végezetinek és az utolsó itilletnek meg gondolatjáért (361a-Ss8a)

Ó, Úr Jézus! Mely rettenetes dolog érteni, hogy... az ördög... Anyaszent-egyházadban... a gonoszságnak sok fiait gyüjthesse... ez utólsó és vissza-vonyó időben... 


\section{Mellékletek}
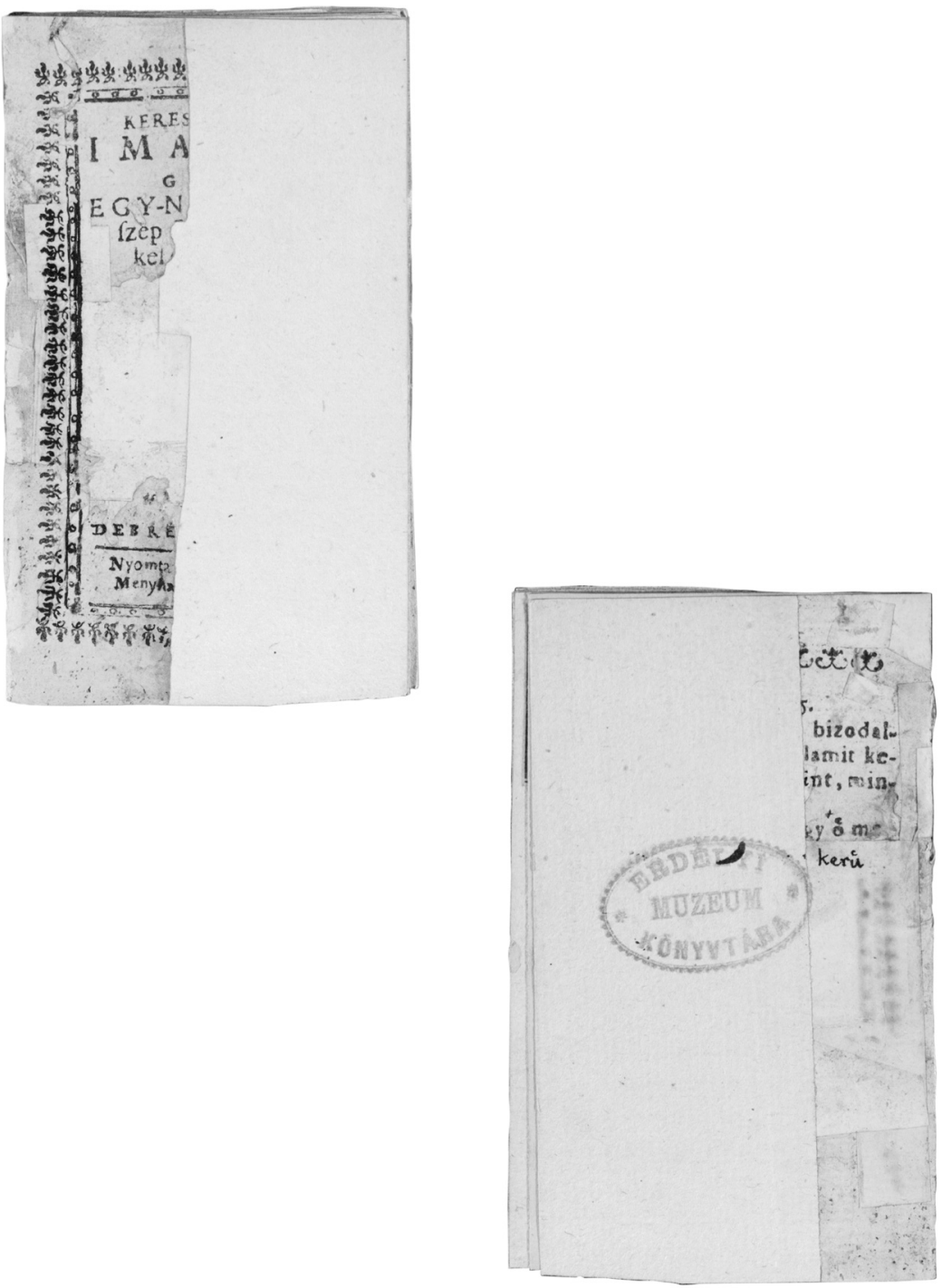

1/1. és1/2. ábra. A Kolozsvárott örzött félcímlap, és az eredeti bélyegzö, a mögötte kilátszó első lappal (lelöhelyét lásd az 1. lábjegyzetben) 


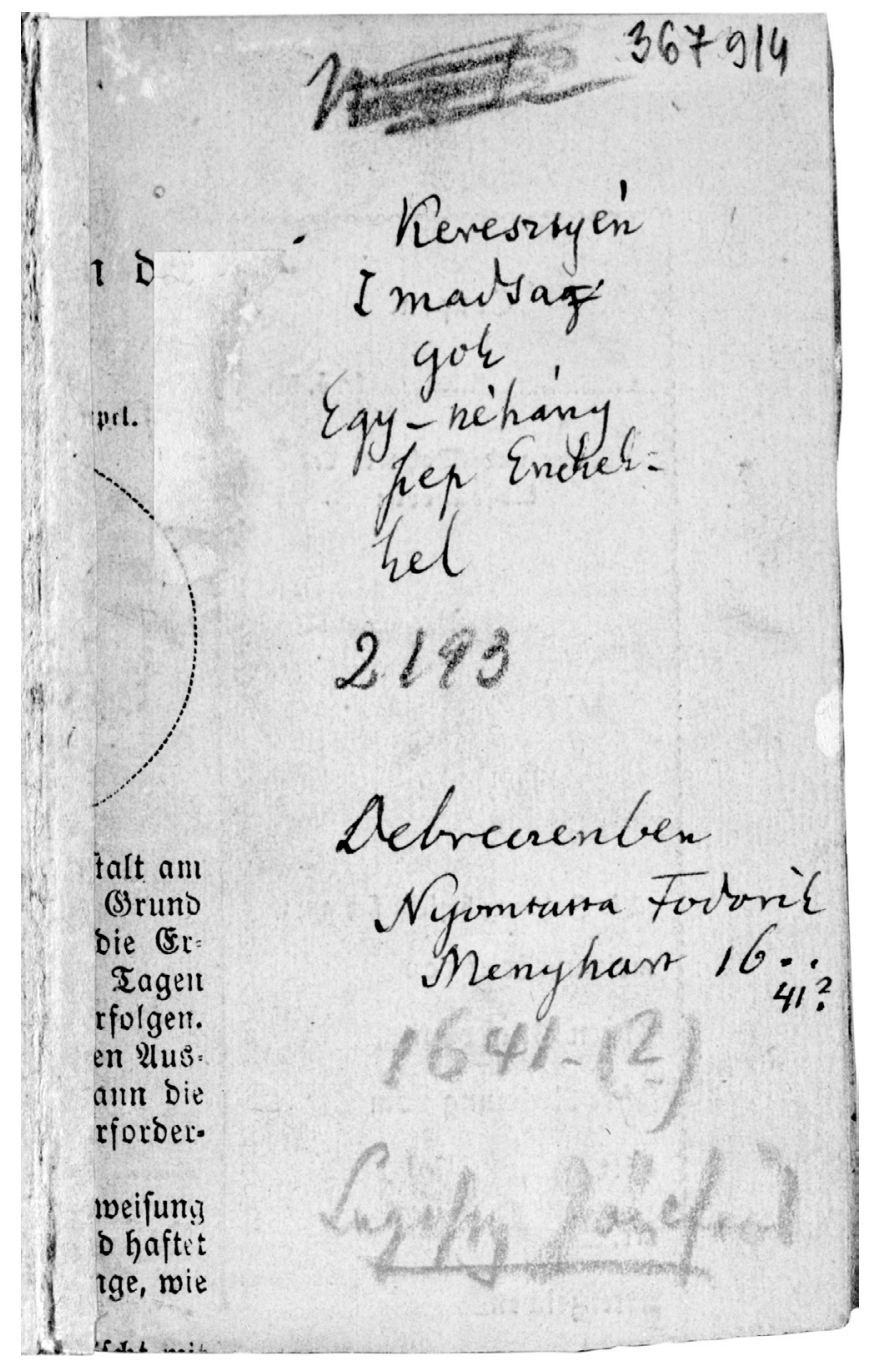

2. ábra. A cím kiegészitése az ajándékozó Lugossy József kézírásával 


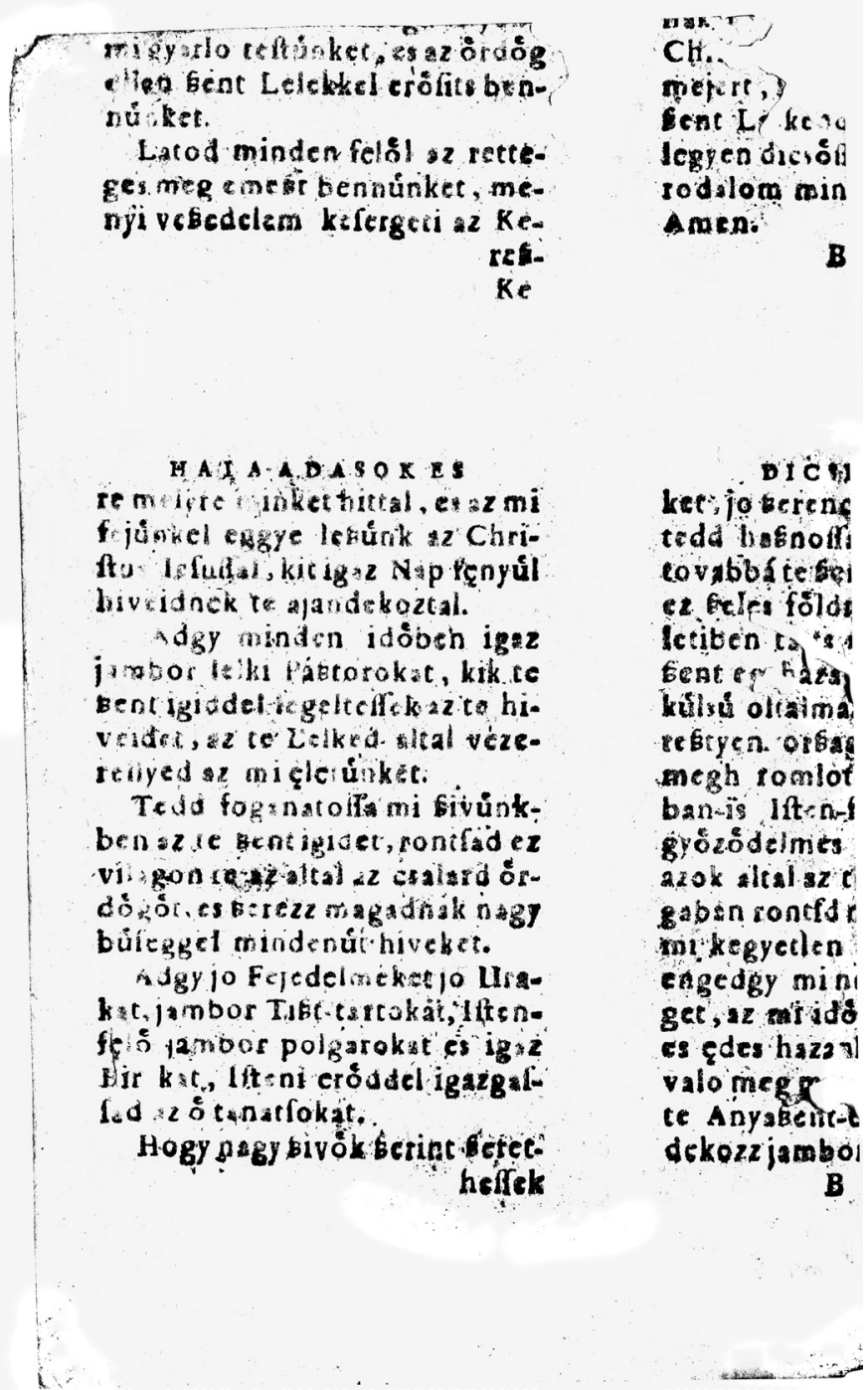

3. ábra. A debreceni töredék, Lugossy József áztatmánya. Lelöhelyét lásd a 2. lábjegyzetben. A B jelü füzet 5. (egy példányban), 9. (három példányban) és 11. levele (hat példányban), különbözö nagyságúra tépve, $35 \times 95$ mm-töl $158 \times 98$ mm-ig 
ritafaes kegyelme által, ki az Io ftennek kent sine elót az mi kónyơrgefưnker foganatoffa tefí , aZ mint Eent Pal Bol, Rom. 8. Az Bent Leiek efedezik mi erettink, meg mondhatatlan fohazkodalokkal

Az Atya Iftennek kegyelme, ah Tefus Cbrifturnak Berelme, es ar Viga B. talu es meg Bentelo ßent Lele hnek mino den ajandeki legyenek mind fejenkent mzKereßtyenekkel, Amen.
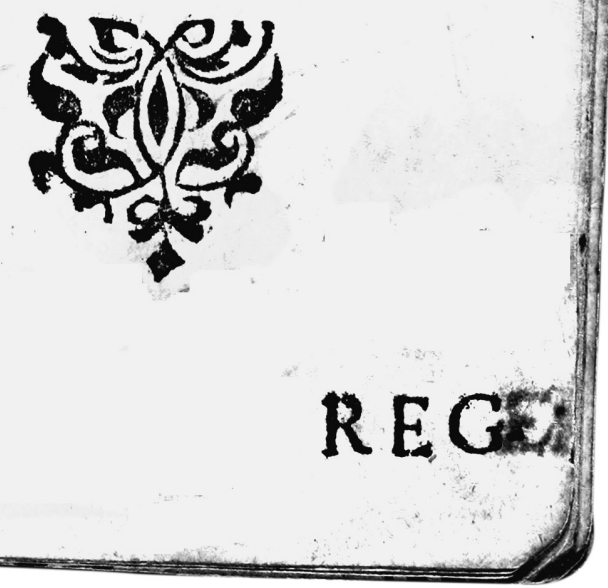

4. ábra. Az elöszó vége a stilizált levelekböl álló, háromszög alakú záródisszel az OSZK példányából (lelőhelyét és a záródisz katalógusbeli számát lásd a 3. lábjegyzetben) 


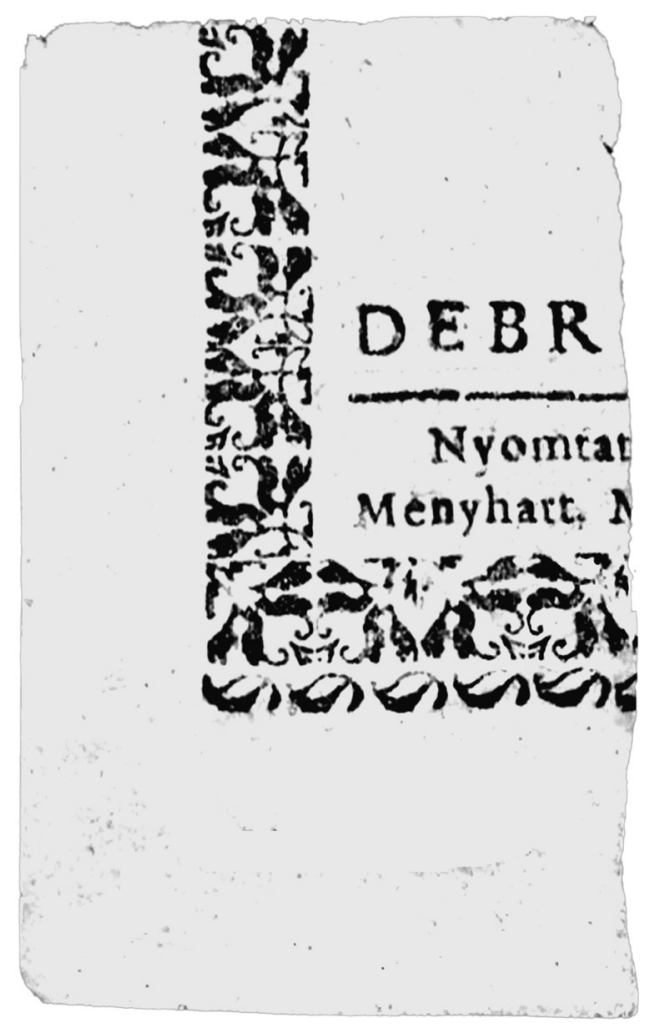

5. ábra. A Sárospatakon örzött címlaptöredék, Harsányi István áztatmánya. Ismeretlen, magyar nyelvü, valószinüleg $8^{\circ}$ formátumú mühöz tartozik (lelöhelyét lásd a 4. lábjegyzetben) 


\author{
Fekete, Csaba
}

\title{
A Collection of Prayers with Hymns of 1641, Debrecen (Early Hungarian Prints 1874)
}

This analytical study detects some of the thus far unclarified connections between similar types of old Hungarian prayers, and adds a suggestion on how to index them, since it is missing from the most important bibliographies like the Early Hungarian Prints (RMNy), volume III. The main problem is that prayers haven't got a characteristic first line (incipit) similar to hymns, on the contrary, these are very often indicated by generalized initiating words such as 'O my God', 'Eternal Father', and so on. Many of them have a general inscription of nothing more, than another, i. e. prayer of the same type or custom. On the other hand, unaltered texts have different titles or inscriptions.

The book type analysed in this study contains topics or one or more prayers in every section, in total 109, each piece is followed by one or more old Hungarian hymns. Nicean, Athanasian Creed and the Te Deum laudamus are considered as prayers. No authors or editors are named. However, dialectal versions of words and orthographic rules in Debrecen during the period in question are outstanding features in this edition, so the circle of the unknown authors and the possible collectors and editors can be narrowed down to this time, i. e. the $17^{\text {th }}$ century.

Twenty prayers are taken from Bullinger's Collection of Prayers, translated into Hungarian by Albert Szenci Molnár (1621). Other prayers had been published in the $16^{\text {th }}$ century, survived in manuscript song collections or appeared decades later in liturgical books or Bible editions, like the one published by Miklós Tótfalusi (1685).

Further investigations have to clarify the connections between the unwritten and the written tradition and dispersion of prayers in the daily use of the community, and in the Reformed worship services in the $16^{\text {th }}$ and $17^{\text {th }}$ century Hungary.

Keywords: Prayers and prayer collections in Hungarian, $16^{\text {th }}$ and $17^{\text {th }}$ centuries, Written and unwritten tradition of liturgy and prayers in the early modern era, Reformed prayer collection of 1641 , Debrecen, Hungary. 